\title{
Effect of Autocorrelation On Temporal Trends In Air-Temperature In A Northern Algeria And Links With Teleconnections Patterns
}

Sabrina Taïbi ( $\nabla$ taibisabrina86@gmail.com)

Université de Blida1 https://orcid.org/0000-0003-1033-1180

Ayoub Zeroual

Ecole Nationale Supérieure d'Hydraulique

Mohamed Meddi

Ecole Nationale Supérieure d'Hydraulique

Research Article

Keywords: temperature, Autocorrelation, Modified Mann-Kendall tests, TFPW-cu, climate indices, Algeria

Posted Date: June 14th, 2021

DOI: https://doi.org/10.21203/rs.3.rs-491178/v1

License: @ (i) This work is licensed under a Creative Commons Attribution 4.0 International License. Read Full License

Version of Record: A version of this preprint was published at Theoretical and Applied Climatology on November 24th, 2021. See the published version at https://doi.org/10.1007/s00704-021-03862-z. 


\section{Abstract}

This study investigates the effect of autocorrelation on temporal trends and step change on monthly, seasonal and annual temperatures of six meteorological stations of the North of Algeria from 1950 to 2016. Afterwards, links between the general atmospheric circulation, via six climate indices, and temperature are examined. Trends of temperature are analysed using six different versions of the Mann Kendall approach while the step change of the time series is computed using the original Pettitt test and the modified-Pettitt. Statistical tests have shown an increase in annual temperatures from 0.8 to $0.9^{\circ} \mathrm{C}$ since the 1980's on the coastal regions and 90's on the highlands. This warming most often exceeds $1^{\circ} \mathrm{C}$ on a seasonal scale, particularly in summer, while no significant trend is observed in winter. On a monthly scale, the increase in temperatures is marked between April and October. The analysis of relationships between six climate indices and average temperatures has shown that inter-annual temperature variability is most often associated with the East Atlantic oscillation for the entire study area. Winter temperatures are influenced by the Mediterranean oscillation as well as the North Atlantic oscillation. The East Atlantic oscillation is the dominant mode of circulation in spring and summer, while in autumn temperatures are strongly linked to West Mediterranean Oscillation. However, no significant correlations have been observed between temperatures and the Arctic Oscillation and El Nino southern oscillation.

\section{Introduction}

Global warming is one of the most sensitive issues of the $21^{\text {st }}$ century; it is considered by many as the most crucial issue facing humanity nowadays (Durand 2007). For several years, the scientific community has been placing increasing importance on climate change, due to the changes observed over the last century. Indeed, since the mid-1970s the earth has experienced considerable climate variability characterized by a temperature increase of about $0.7^{\circ} \mathrm{C}$ (IPCC 2007, 2014). This global warming has resulted in the appearance and persistence of some extreme events such as droughts and floods, which have affected water availability, agriculture and other socio-economic factors (Radhouane 2013; Chebil et al. 2011 Boko et al. 2007 Sowers et al. 2011 ). The Mediterranean basin having suffered cumulative impacts from climate change is considered as a hot-spot area that requires more attention for the implementation of adaptation measures (Giorgi 2006). In fact, an increase in temperatures has been observed in France (Chaouche et al. 2010), Spain (Ramos et al., 2012), Italy (Bartolini et al. 2012), Greece (Mamara et al. 2016; Feidas et al. 2016) and Turkey (Dogan et al. 2015). However, this upward trend varies considerably both spatially and temporally and is most significant in spring and summer. Consistent with these results, the countries on the southern shore of the Mediterranean, including Algeria, are no exception to the consequences of climate change (Price 2017). Observed annual and seasonal trends in mean temperature indicate global warming that is significantly beyond the range of changes due to natural variability (IPCC 2014). The annual temperature trend observed in Morocco and Tunisia shows an increase of 0.2 to $0.4^{\circ} \mathrm{C}$ per decade (Driouch et al. 2013). Dorte (2013) has found that average temperatures in Tunisia increased by about $1.4^{\circ} \mathrm{C}$ during the $20^{\text {th }}$ century from the 1970 s onwards, while Filahi et al. (2016) noted a considerable increase in autumn and spring temperatures in Morocco during the period 1970-2012.

Air temperature plays a key role in understanding the complex climate system and it is one of the crucial variables affecting almost all environmental processes (Vancutsem et al. 2010). In addition, the identification of temperature trends is essential in the studies of climate change impacts on the hydrological cycle, environment and agriculture (Yu et al. 2019).

A slight increase in temperature can trigger hydrological droughts and floods (Dai 2011) and even air pollution (Zhang 2017). A better understanding of the temporal variability of temperatures is essential for the implementation of more effective climate change adaptation measures for sustainable water resources management and agriculture.

In Algeria, although much work has been devoted to the study of regional and local climate (Meddi 2009; Bekoussa 2008; Medjerab and Hania 2005) few studies have addressed the characterization of air temperature variation (Zeroual et al. 2017). To our knowledge, all previous studies have focused on the analysis of spatial and temporal variation of precipitation and the impact of climate change on water resources. Some of them reported a decrease in rainfall particularly in the north-western part of Algeria (Meddi et al 2009 Bekoussa et al 2008 Medjerab and Hania 2005; Taibi et al. 2013) as well as a lowering of groundwater levels and the drying up of some karstic springs (Bensaoula et al. 2019; Bouabdelli et al. 2020). Additionally, Zeroual et al. (2019) found that the surface area of desert zones has increased considerably to the detriment of the warm temperate climate zone, which is entirely humid.

Furthermore, the statistical tests of Mann-kendall (Mann 1945; Kendall 1976) and Pettitt (1979) are among the methods of analyzing the temporal variability of temperatures, most often used for trend analysis and step change detection, respectively. However, studies have shown that it is essential to take into account the effect of auto-correlation when analysing the temporal variability of a data set (von Storch 1995; Serinaldi and Kilsby 2016; Yue et al. 2002 Piyoosh et al. 2017; Zamani et al.2017; Fathian et al. 2016; Datta et al. 2019). To this end, approaches have been developed to eliminate the influence of auto-correlation, such as the pre-whitening procedure (von Storch 1995), trend free prewhitening (TFPW) (Yue et al. 2002) and trend free prewhitening corrected unbiaised (Serinaldi and Kilsby, 2016). On the other hand, other methods suggest a correction of the variance of the Mann-Kendall test through the use of empirical formulas (Hamed and Ramachandra Rao 1998) and Monte Carlo simulations (Yue and Wang 2004). Due to the existence of long-term persistence within a climate datase which can also influence the trend, another approach of the modified Mann kendall test has been proposed by Hamed (2008) and Kumar (2009). All these methods are increasingly used in recent studies that aim to show the effect of auto-correlation in the analysis of trends in a time series of climate data (e.g. Zamani et al. 2017 ; Fathian et al. 2016 ; Datta et al. 2019). Consequently, one of the main objectives of this study is to characterise the long-term variability of temperatures in Northern Algeria through six meteorological stations distributed between the coastal region and the highlands during the period 1950-2016, through the application of the various approaches mentioned below.

In northern Algeria, climate variability is associated with certain atmospheric circulation modes such as the North Atlantic Oscillation (NAO), the Mediterranean Oscillation (MO), the Southern Oscillation (ENSO) and the Western Mediterranean Oscillation (WMO) (Taibi et al. 2015; Zeroual et al. 2017). In addition to its four circulation modes, the Eastern Oscillation (EA) and the Arctic Oscillation (AO) have also been shown to influence temperature variability in 
the Mediterranean region (Toreti et al. 2010; Rios-Cornejo et al. 2015). It has to be noted that little is known about the links between the temperatures of Northern Algeria and the atmospheric circulation patterns (e.g. Zeroual et al. 2017). Relevant to this, the second objective of this work is to analyse the relations that might exist between temperature variability and climatic indices.

Furthermore, this study provides a complete analysis of the long-term temperature evolution, trend, break, persistence and their relationship with six modes of atmospheric circulation at different annual, seasonal and monthly time steps over the period 1950-2016, which is significant for climate prediction on a regional scale, in order to carry out necessary socio-economic impact studies for the implementation of plans supporting sustainable management of water resources and agriculture in Algeria. These approaches have already been the subject of several recent studies in different regions of the world (Plewa et al. 2019; Yu et al. 2019; Lee et al. 2019).

\section{Materials And Methodology}

\subsection{Study area}

Our study was conducted on the northern part of Algeria located in northern Africa and on the southern shore of the Mediterranean (fig. 1), bounded to the east by Tunisia, to the west by Morocco and to the south by the Saharan Atlas. The climate that characterizes the study area is Mediterranean on the coast and semi-arid on the highlands. Landform is more accentuated in the East than in the west of Algeria, it is for this reason that the precipitation varies from approximately $700 \mathrm{~mm}$ to the East (Annaba) and less than $300 \mathrm{~mm}$ to the West (Oran). A rainfall gradient is also observed from North to South where the annual totals vary from approximately $600 \mathrm{~mm}$ (Algiers) to less than $200 \mathrm{~mm}$ (Djelfa).

\subsection{Data description}

Six temperature series were selected to characterize the spatiotemporal variability of annual and monthly temperatures in northern Algeria. The choice of these meteorological weather stations is based on spatial representativeness and the availability of data. The work carried out by Taibi et al. (2015) highlighted a division of northern Algeria into 6 rainfall regions. For this purpose, we have selected a station by region (fig. 1), namely: the center (Algiers), the East (Annaba), the West (Oran), the eastern highlands (Constantine), the highlands West (Mascara) and the steppes (Djelfa). There are a large number of meteorological weather stations, however most temperature data are only available from the 1970s and 1980s. The monthly data for the six meteorological weather are available from 1950 to 2016 except for the stations of Djelfa and Mascara (Table 1). These data were collected from the National Meteorological Office (NMO).

Table 1 : Names and geographic coordinates of stations

\begin{tabular}{|lllll|}
\hline Stations & Latitude & Longitude & Altitude $(\mathrm{m})$ & Study period \\
\hline Algiers (Dar el Beida) & $36^{\circ} 43$ & $03^{\circ} 15 \mathrm{E}$ & 25 & $1950-2016$ \\
\hline Annaba & $36^{\circ} 50$ & $07^{\circ} 49 \mathrm{E}$ & 4 & $1950-2016$ \\
\hline Constantine & $36^{\circ} 17$ & $06^{\circ} 37 \mathrm{E}$ & 694 & $1950-2016$ \\
\hline Oran & $35^{\circ} 38$ & $00^{\circ} 36 \mathrm{~W}$ & 90 & $1950-2016$ \\
\hline Mascara & $35^{\circ} 13$ & $00^{\circ} 09 \mathrm{E}$ & 513 & $1977-2016$ \\
\hline Djelfa & $34^{\circ} 20$ & $03^{\circ} 23 \mathrm{E}$ & 1180 & $1972-2016$ \\
\hline
\end{tabular}

\subsection{Climate indices}

The NAO, SOI and MO data were downloaded from the Climatic Research Unit website

(http://www.cru.uea.ac.uk/cru/data/pci.htm). While, the AO and EA indices were downloaded from the NOAA website (http://www.cpc.ncep.noaa.gov/products/precip/CWlink/daily_ao_index/ao.shtml and http: //www.cpc .ncep.noaa.gov / data / teledoc / ea.shtml). The WMO index was implemented by Martin-Vide and Lopez-Bustins (2006) from the University of Barcelona (http://www.ub.edu/gc/en/2016/06/08/wemo/).

The NAO index is defined as the difference of the atmospheric pressure at sea level between Azores anticyclone (Lisbon) and the depression of Iceland (Reykjavik) (Hurell 1995). NAO has a north-south fluctuation in air from the Arctic and Icelandic regions to the subtropical high-pressure belt, which has the effect of varying the intensity of the position of the Azores anticyclone and the Icelandic depression. This coupled phenomenon forms a balancing effect: when the pressure is relatively high in the subtropical belt, it is relatively low in the polar region and vice versa.

The $(\mathrm{AO})$ is a large-scale pattern of variability throughout the whole of the Northern hemisphere circulation closely linked to the NAO (Ríos-Cornejo et al. 2015). Thompson and Wallace $(1998,2000)$ suggested that the NAO is the regional manifestation of the AO circulation mode. The AO index was calculated by Thompson and Wallace (2000) as the leading EOF of the monthly mean SLP over the northern hemisphere north of $20 \mathrm{~N}$.

The EA pattern as defined by Wallace and Gutzler (1981) and Barnston and Livezey (1987) is considered as the second prominent mode of low frequency variability over the North Atlantic and appears as a leading mode in all months (NOAA 2018). The EA is structurally similar to the NAO and consists of a north-south dipole of centers of anomalies covering the North Atlantic from east to west. The EA centres of anomaly are shifted southeast to the approximate nodal lines of the NAO model. It is for this reason that the EA is often interpreted as a NAO shifted towards the south. However, the lower-latitude center contains a strong subtropical link in association with modulations in the subtropical ridge intensity and location. This subtropical link makes the EA pattern distinct from its NAO counterpart (NOAA 2018). 
The MO designates the difference normalized pressure at the $500 \mathrm{hPa}$ geopotential level between Algiers and Cairo (Conté et al., 1989). The MO results from the opposite behavior of barometric, thermal and pluviometric variability between the the western and eastern Mediterranean

ENSO pattern is represented by the south oscillation index (SOI) which is defined as the pressure difference between Tahiti and Darwin. Tahiti represents the high subtropical pressures of the eastern Pacific, and Darwin represents the low equatorial pressures of the northern Indian Ocean and Indonesia.

Martin-Vide and Lopez-Bustins (2006) proposed a new regional telecommunication index defined from synoptic data from the western Mediterranean basin and its surroundings and which they called the Western Mediterranean Oscillation (WeMO). The WeMO index indicates the pressure difference between the regions of the north of the Italian peninsula and the south-west of the Iberian Peninsula.

\subsection{Methods}

\subsubsection{Autocorrelation}

In any trend or step analysis exercise, it is also important to evaluate the existence of serial correlation. In such cases, the presence of serial correlation in the time series can impact considerably the outcome of trend analysis. Positive autocorrelation can artificially induce trend in a time series (e.g. von Storch 1995; Kulkarni and von Storch 1995), while negative autocorrelation can weaken the trend if it is in fact present (Yue et al, 2002). Such statistical features have serious implications for trend and step analyses. The time series of temperature data require to be verified for autocorrelation before applying a trend tests and step analysis. The autocorrelation of a time series $X_{-} t$ means that this latter is linked with its own previous ( $\left.t-K\right)$ or following ( $\left.t+K\right)$ values (Cunderlik and Burn 2004). This dependence of time series is measured by the coefficients of the autocorrelation at different lag-time ( $k$ ). The hypothesis of serial independence is checked by t test statistic (Mondal et al. 2012). The null hypothesis that $\hat{\rho}=0$ is tested against the alternative hypothesis that $\hat{\rho} \neq 0$. If $|t|>t_{\alpha / 2}$ we reject the null hypothesis, at a significance level of $a$. In the case of this work, the autocorrelation coefficient was calculated for a shift $k=1$ (Lag1) at a significance level of $5 \%$.

\subsubsection{Mann-kendall test and sen's slope}

The Mann-Kendall (MK) test (Mann 1945 and Kendall 1975) allows to detect the existence of a significant global trend within a time series data as well as the direction of the trend. Trends are assessed by estimating the Sen slope (Sen 1968) associated with the Mann-Kendall test. It is a non-parametric method based on the median slope. The latter being less sensitive to outliers than traditional regression methods, it allows a more reliable assessment of the trend (Eichner et al. 2003).

\subsubsection{Modified Mann-kendall (MMK)}

In order to eliminate the effect of autocorrelation on temporal trends in the time series, several authors have modified the Mann-kendall test according to different approaches. As part of our work, six statistical modified tests based on three different approaches were used.

\section{a) Approaches based on prewhitening}

The three approaches used are those proposed by von Storch (1995) Yue et al. (2002) and Serinaldi and Kilsby (2016). Von storch (1995) developed the prewhitening method (MMK-PW) and suggest using it when the series has a lag-1 autocorrelation otherwise the original Mann-kendall test is sufficient. Afterwards, Yue et al. (2002) proposed the TFPW method to also addressed the autocorrelation in time series data. However, Serinaldi and kilsby (2016) have shown that the trend-free-pre-whitening approach (TFPW) does not considered the variance inflation of the uncorrelated residues and is not able to provide a pre-whitened of the time series used for the modified Mann-Kendall test. To that effect, it suggested the corrected and unbiased trend-free-pre-whitening (TFPWcu) approach (Serinaldi and kilsby 2016).

\section{b) Approaches based on variance correction}

The modification of the variance of the Mann-Kendall test is an approach proposed by Hamed and Rao (1998) (MMKH) and Yue and Wang (2004) (MMKY). The variance correction is done by empirical formulas for the MMKH test, while the MMKY test uses the Monte-Carlo simulations to remove the effect of the auto-correlation in the MK test.

\section{c) Long term persistance (LTP)}

Some studies have shown that long-term persistence (LTP), also known as the Hurst phenomenon, can underestimate the importance of the trend in climate variability (Koutsoyiannis 2003; Koutsoyiannis and Montanari 2007; Hamed 2008). To this end, Hamed (2008) modified the MK test to consider this phenomenon in the time series. This method was used as part of this work to verify the long-term persistence of temperatures in Northern Algeria. For more information, the article of Kumar (2009) illustrates in detail the different stages of this method.

\subsubsection{Pettitt test}

The Pettitt test (Pettitt 1979) is a non-parametric test used to verify the stationarity of a series of data. The null hypothesis of this test means that the series is stationary while the alternative hypothesis means that the data series is not stationary and that a break point of mean exists from a given date.

\subsubsection{Modified Pettitt test using TFPW-cu}


Serinaldy and klisby (2016) proposed the corrected and impartial TFPW (TFPW-cu) method to eliminate the effect of the autocorrelation of the Pettitt test (1979). This test is applied when one wishes to detect a breaking point within a series of autocorrelated data. The mathematical equations and the sequential steps of the framework are explained in detail in Serinaldy et klisby (2016) and Achour et al. (2020).

\subsubsection{Pearson coefficient correlation}

To explore the links between average temperatures and climate indices the Pearson correlation coefficient is used. This coefficient has already been used in numerous studies to demonstrate the influence of general atmospheric circulation on climate variability (eg. Plewa et al., 2019; Ríos-Cornejo et al., 2015; Yu et al., 2019...etc.).

\section{Results}

\subsection{Autocorrelation analysis}

Before analyzing the trends in the temperature time series, we investigate the autocorrelation as suggested by Hamed and Rao (1998) and Serinaldi and Kilsby (2016). The autocorrelation is checked at the different annual, seasonal and monthly time steps. Fig. 2 represents the auto-correlogram for each station, the autocorrelation coefficient was determined for a lag- 1 . The temperature series is autocorrelated to the significance threshold of $5 \%$ when its value is above (below) that of the upper (lower) limit. The results highlight the presence of an auto-correlation for all the annual average temperature series. At the seasonal scale, the autocorrelation is observed in autumn, spring and summer at the stations of Algiers, Annaba, Oran and Constantine, while it is observed in spring and summer at Mascara and only in autumn at Djelfa station. Winter temperature series are not auto-correlated for all stations.

On a monthly scale, the presence of autocorrelation in the data series differs from one station to another (fig.2). The monthly temperatures for April, June, July, and August are autocorrelated at Algiers station, while at Annaba and Constantine stations, autocorrelation is observed only in August and October. It is at Oran station that autocorrelation is strongly present since it is detected within the monthly series going from March to August. The monthly data series for March, June and August are also autocorrelated at the Mascara station, contrary to the Djelfa station which is characterized by the absence of autocorrelation on a monthly scale. The results also show that the autocorrelation detected within the different data series is positive, which according to Hamed and Rao (1995) which would further increase the probability of detecting a trend then it does not exist (Serinaldi and Kilsby 2016). It therefore becomes essential to eliminate autocorrelation to analyze temperature trends, by applying the different methods illustrated in section (2.4).

\subsection{Temperature trend analysis}

The Mann-kendall test is most often used to analyze trends in a time series data. However, the presence of autocorrelation may influence the results obtained. For this purpose, we analyzed the trend of the mean temperature series using the original Mann Kendall test as well as six other MMK tests developed using different approaches in order to eliminate the effect of autocorrelation. It is a question of comparing for each station the results of the $Z$ obtained by the seven statistical tests with the different time steps annual, seasonal, and monthly, only for the auto-correlated series. When the series is not auto-correlated, only the original Mann-Kendall test is applied. A trend is said to be significant when Z is greater (or less) than 1.96 (-1.96). The sen slope is also calculated to measure the magnitude of warming (or to quantify the variation in temperatures by decades).

In Algiers station, the analysis of the trend in annual temperatures series by the MK test highlights a significant positive trend ( $Z=3.99)$ (table 2$)$. This time series is autocorrelated and eliminating the effect of autocorrelation using the different approaches of MMK also showed the presence of a positively significant trend except the LTP test (table2). The results show a slight decrease in the $Z$ value after elimination of the autocorrelation and removing the effect of the Hurst coefficient $(H)$ compared with the original $M K(2.97<Z<3.13)$ except for the TFPW method which shows an increase in the $Z(Z=4.69)$. However, the LTP method show the presence of long-term persistence $(\mathrm{H}=0.73$ with $P$-value $=0.001)$ and their removal from the time series made the trend not significative $(Z=1.53)$. The Sen slope indicates an increase of $0.16^{\circ} \mathrm{C} /$ decades of annual temperatures.

On a seasonal scale, all statistical tests show a positive non-significant trend in winter, with a $Z$ which varies between 0.7 and 0.8 . In spring, the MK, TFPW and MMKY tests show a positive significant trend in the temperatures autocorrelated series $(1.98<Z<2.87)$, while the TFPW-cu and MMKH tests do not show a significant trend, the $Z$ value being 1.56 and 1.63 respectively. The LTP method show the presence of long-term persistence $(\mathrm{H}=0.75$ with $P$-value $=0.000)$ and their removal from the time series made the trend not significative $(Z=0.98)$. The Sen slope shows an increase in temperatures of $0.13^{\circ} \mathrm{C} /$ decade. In summer, all of the statistical tests indicate a positive significant trend $(3.74<Z<4.51)$ with the absence of long-term persistence $(Z$-LTP $=2.52)$. The autocorrelation observed in this data series had no effect on the result obtained by the original MK, which shows the magnitude of the trend during this season which results in an increase of $0.3^{\circ} \mathrm{C} /$ decade. In autumn, an increase of $0.17^{\circ} \mathrm{C} / \mathrm{decade}$ is observed. Indeed, the original MK test indicates a positive significant trend $(Z=3.37)$. Analysis of the temperatures after elimination of the autocorrelation by the PW, TFPW, TFPW-cu, MMKH and MMKY tests also shows a significant trend, the values of $Z$ are respectively $2.68,3.46,2.72,2.52,2.92$. However, the LTP method show the presence of long-term persistence $(H=0.64$ with $P$-value $=0.025)$ and their removal from the time series made the trend not significative $(Z=1.73)$.

On a monthly scale, all the statistical tests show a positive trend without significance in January, March, September, November and December, while a nonsignificant negative trend is observed in February. MK test shows significant positive trend in April $(Z=2.83)$. Even if the elimination of the autocorrelation effect by the various tests indicates a decrease in the $Z$ value $(2.20<Z<2.82)$, the trend remains significant, which shows the extent of the warming during this month which is $0.17^{\circ} \mathrm{C} /$ decade. In contrast, the LTP method show the presence of long-term persistence $(\mathrm{H}=0.67$ with $\mathrm{P}$-value $=0.007)$ and their removal from the time series made the trend not significative $(Z=1.29)$. In May, the Mann-Kendall test highlights a significant positive trend $(Z=2.25)$ which results in an increase in temperatures of around $0.2^{\circ} \mathrm{C} /$ decade. The monthly autocorrelated temperatures observed in June, July and August indicate a significant positive trend by all of the statistical tests as well as the presence of long-term persistence. The registered $Z_{\text {LTP }}$ is 2.13 (June), 2.85 (July) and 2.13 (August)

Page $5 / 24$ 
respectively (see Table xx). The impact of global warming in the summer months translates into a dramatic rise in temperatures of around $0.3^{\circ} \mathrm{C} / \mathrm{decade}$. The month of October recorded a significant positive trend much more important than the other months which is manifested by a significant rise in temperatures of around $0.33^{\circ} \mathrm{C} /$ decade.

In Annaba station, the analysis of annual temperatures by the $M-K$ test highlights a significant positive trend $(Z=4.03)($ table 2$)$. The elimination of autocorrelation by the PW, TFPW, TFPW-cu, MMKH and MMKY tests also shows a positive trend, the Z statistic is $2.17,4.04,2.18,2.62,3,22$ respectively. On the other hand, a presence of long-term persistence is detected $(\mathrm{H}=0.69$ with $\mathrm{P}$-value $=0.004)$ and their removal from the time series made the trend not significative $(Z=1.75)$. The Sen slope indicates an increase of $0.13^{\circ} \mathrm{C} /$ decade.

On a seasonal scale, all of the statistical tests indicate a positive trend without significance in winter temperatures series $(0.81<Z<1.20)$. In spring, a significant positive trend is observed, including after eliminating the effect of autocorrelation $(2.15<Z<4.34)$. However, the LTP method show the presence of long-term persistence $(\mathrm{H}=0.66$ with $\mathrm{P}$-value $=0.012)$ and their removal from the time series made the trend not significative $(Z=1.69)$. The recorded Sen slope is around $0.14^{\circ} \mathrm{C} /$ decade. In summer and in Autumn, a significant positive trend is detected by all of the statistical tests, which translates into an increase of around $0.2^{\circ} \mathrm{C} /$ decade. The elimination of autocorrelation did not influence the result obtained by MK (see fig.) and the LTP test reveals long-term persistence in autumn $(\mathrm{H}=0.62$ with $\mathrm{P}$-value=0.042) and despite their elimination the trend remains significative $(\mathrm{Z}=2.05)$.

On a monthly scale, all of the statistical tests indicate a positive non-significant trend in January, March, September, November and December, as well as a non-significant negative trend in February. In April and May a significant positive trend be highlighted by all the statistical tests (see fig.) which manifests itself by an increase of about $0.2^{\circ} \mathrm{C} /$ decade. No long-term persistence is detected in April and May, which register a Z of 2.05 and 2.11 respectively. All of the statistical tests show a significant positive trend in June and July, which recorded an increase of 0.18 and $0.23^{\circ} \mathrm{C} /$ decade respectively.

On the other hand, long-term persistence is detected only in August $(\mathrm{H}=0.6$ with $\mathrm{P}$-value $=0.042)$. Analysis of the autocorrelated time series of temperatures for the month of August by the MK test shows a positive significant trend $(Z=2.42)$. The TFPW, MMKH and MMKY tests show the same result, contrary to the PW and TFPW-cu and LTP tests which indicate the absence of a significant trend after elimination of the effect of autocorrelation and long-term persistence. The month of October recorded a significant increase in temperatures of about $0.3^{\circ} \mathrm{C} /$ decade. All the statistical tests show a significant trend in the autocorrelated time series $(2.96<Z<3.88)$ as well as the absence of long-term persistence $(Z=2.64)$.

At Oran station, the analysis of annual temperatures by the MK test shows a significant positive trend $(Z=3.69)$ (table 2$)$. The two prewhitening methods PW and TFPW-cu highlight the absence of a significant trend with a Z values of 1.69 and 1.86 respectively, while the tests TFPW, MMKH and MMKY respectively show a significant trend with a $Z$ values of $3.95,1.98,2.63$. Whereas, the LTP method show the presence of long-term persistence $(\mathrm{H}=0.8$ with $P$-value $=0.00)$ and their removal from the time series made the trend not significative $(Z=1.17)$. The Sen slope indicates an increase of $0.14^{\circ} \mathrm{C} /$ decade of annual temperatures

On a seasonal scale, all of the statistical tests show a positive trend without significance in winter temperatures $(1.03<Z<1.31)$. In spring, the autocorrelated temperature series shows a significant positive trend $\left(Z_{M K}=3.07\right)$ characterized by an increase of $0.16^{\circ} \mathrm{C} /$ decade. The elimination of the effect of autocorrelation by the tests PW, TFPW-cu and MMKH, LTP respectively show a Z of 1.49, 1.54, 1.64 and 0.92 , while the tests TFPW and MMKY respectively indicate a $Z$ of 3.33 and 2.12. In this case, the methods developed by Von storch (1995), Serinaldi and kilsby (2016) and Hamed and Rao (1998) are the most effective in eliminating the effect of autocorrelation. In summer, all of the statistical tests show a significant positive trend $(2.18<Z<3.23)$ in the autocorrelated temperature series and is manifested by an increase of $0.18{ }^{\circ} \mathrm{C} /$ decade. However, the elimination of the long-term persistence made the trend not significative $\left(Z_{\text {Ltp }}=1.52\right)$. In the autumn season, the analysis of the autocorrelated time series by the MK test shows a significant positive trend characterized by an increase of $0.13^{\circ} \mathrm{C} /$ decade. On the other hand, the PW and TFPW-cu tests indicate a non-significant trend $(Z=1.93)$, while the TFPW, MMKH and MMKY tests show a $Z$ of 2.60, 2.23 and 2.09 respectively and the elimination of the long-term persistence made the trend not significative $(Z L t p=1.30)$.

On a monthly scale, the analysis of the temperature series in January, February, March, November and December by all the statistical tests show a positive trend without significance as well as the presence of long-term persistence in March.

In April, the autocorrelated temperature series shows a significant positive trend accompanied by an increase of $0.2^{\circ} \mathrm{C} /$ decade. The statistic $Z$ calculated for the MK, TFPW, TFPW-cu, MMKH and MMKY tests is 3.28, 3.34, 2.03, 3.89 and 2.77 respectively, while the PW test highlights an insignificant trend $(Z=1.83)$ and the LTP does detect long-term persistence $\left(H=0.63\right.$ with $P$-value $=0.027$ and $\left.Z_{\text {LTP }}=1.70\right)$.

Analysis of the May temperature series by the MK test reveals a significant positive trend characterized by an increase of $0.18{ }^{\circ} \mathrm{C} / \mathrm{decade}$, while all of the approaches used to eliminate the autocorrelation effect and the LTP indicate a non-significant trend (see fig.) except the TFPW method (Z = 2.38). In June and July all statistical tests (except LTP) indicate a significant positive trend even after elimination of the autocorrelation effect (table 2). These two months recorded an increase of 0.25 and $0.2^{\circ} \mathrm{C} /$ decade respectively.

Analysis of the temperature series for the month of August shows a significant positive trend detected by all of the statistical tests except TFPW-cu which indicates a $Z$ of 1.95 as well as the presence of long-term persistence $\left(H=0.62\right.$ with P-value $=0.052$ and $\left.Z_{L T P}=1.50\right)$. The Sen slope shows an increase in temperatures of $0.14{ }^{\circ} \mathrm{C} /$ decade. The MK test indicates a significant positive trend in temperatures observed in September and October, which manifests itself respectively by an increase of 0.13 and $0.27^{\circ} \mathrm{C} /$ decade.

At Constantine station, the analysis of trends in annual temperatures by all the statistical tests shows a significant positive trend which results in an increase of $0.16^{\circ} \mathrm{C} /$ decade. On the other hand, LTP does not detect long-term persistence $\left(H=0.48\right.$ with $P$-value $=0.617$ and $\left.Z_{\text {LTP }}=1.61\right)$. 
On a seasonal scale, the winter temperatures observed in Constantine indicate a positive trend without significance (see fig.). In spring, the temperature analysis by the MK test shows a significant positive trend characterized by an increase of $0.2^{\circ} \mathrm{C} /$ decade. After eliminating the autocorrelation effect, the TFPW, MMKH and MMKY tests always indicate the presence of the significant trend, unlike the PW and TFPW-cu tests which show an insignificant trend and record a $Z$ value respectively of 1.94 and 1.89 . The elimination of the long-term persistence made the trend not significative $(Z=1.71)$.

In summer season, an increase of $0.27^{\circ} \mathrm{C} /$ decade of temperatures is observed. In fact, all of the statistical tests (except LTP) show a significant positive trend in temperatures, which highlights the extent of the warming during this season (see fig.). In autumn, the analysis of the autocorrelated series of temperatures by the MK, TFPW, MMKH and MMKY tests shows a significant positive trend $(2.09<Z<2.70)$, while the PW and TFPW-cu tests indicate a positive trend without significance with the statistic $Z$ is 1.74 and 1.79 respectively. The elimination of the long-term persistence also made the trend not significative $(Z=1.13)$. However, the Sen slope indicates an increase of $0.15^{\circ} \mathrm{C} /$ decade.

At a monthly scale, the Mann-Kendall test shows a non-significant positive trend in January, March, November and December and a non-significant negative trend in February and September (see fig.). The months of April, May, June and July recorded increases of $0.26,0.27,0.31$ and $0.29{ }^{\circ} \mathrm{C} /$ decade, respectively. Indeed, the Mann-kendall test (as well as the other tests) shows a significant positive trend (see fig.). Analysis of the autocorrelated temperature series for the month of August by the MK, TFPW, MMKH and MMKY tests shows a significant positive trend $(2.03<Z<2.68)$, while the PW and TFPW-cu tests do not show significant trend and indicate a $Z$ of 1.60 and 1.75 respectively. The Sen slope shows an increase of $0.2^{\circ} \mathrm{C} /$ decade. In October, all of the statistical tests show a positive trend in the autocorrelated temperature series $(254<Z<3.41)$ as well as the absence of long-term persistence $(H=p v a l u e=Z=2.13)$. The Sen slope indicates a significant increase in temperatures of around $0.4^{\circ} \mathrm{C} /$ decade which shows the extent of the warming during this month.

In Mascara station, the analysis of annual temperatures (autocorrelated series) during the period 1977-2016 by all of the statistical tests shows a significant positive trend which results in an increase of $0.4^{\circ} \mathrm{C} /$ decade (table 2). However, the LTP method show the presence of long-term persistence $(\mathrm{H}=0.7$ with $\mathrm{P}$ value $=0.009)$ and their removal from the time series made the trend not significative $(Z=1.81)$.

On a seasonal scale, temperatures do not show a significant trend in winter, while in spring and summer (autocorrelated series) a significant positive trend is demonstrated by all of the statistical tests which are reflected respectively by an increase of 0.55 and $0.67{ }^{\circ} \mathrm{C} /$ decade. The LTP test also indicates the absence of long-term persistence in spring $(\mathrm{H}=0.37$ with $\mathrm{P}$-value $=0.778)$ and summer $(\mathrm{H}=0.52$ with $\mathrm{P}$-value $=0.294)$ which have a significative trend with $\mathrm{Z}$ of 4.01 and 2.68 respectively. The elimination of the autocorrelation effect did not influence the temperature trend given the extent of warming observed in spring and summer. The MK test also indicates a positive trend in temperatures in autumn, which is manifested by an increase of $0.38{ }^{\circ} \mathrm{C} / \mathrm{decade}$.

On a monthly scale, the MK test highlights an insignificant trend in temperatures in January, February, March, September, November and December. The temperatures observed in April and May show a significant positive trend (see fig.) which reflects respectively into an increase of 0.54 and $0.92^{\circ} \mathrm{C} /$ decade. In June, the MK test shows a significant positive trend in temperatures which is manifested by an increase of $0.74{ }^{\circ} \mathrm{C} / \mathrm{decade}$. This trend also persists after eliminating autocorrelation, which shows the extent of the warming during this month. A significant positive trend is also observed in July, the Sen slope associated with the MK test shows an increase of $0.78^{\circ} \mathrm{C} /$ decade. In August, the MK, TFPW, MMKH and MMKY tests show a significant positive trend while the PW and TFPW-cu tests show a non-significant trend. The Sen slope associated with the MK test shows an increase of $0.61{ }^{\circ} \mathrm{C} /$ decade. The MK test shows a significant positive trend in temperatures in October accompanied by an increase of around $0.7^{\circ} \mathrm{C} /$ decade. the LTP method show the presence of long-term persistence only for June $(\mathrm{H}=0.63$ with $\mathrm{P}$-value $=0.047)$ and September $(\mathrm{H}=0.64$ with $\mathrm{P}$-value $=0.041)$ and their removal from the time series made the trend not significative $(\mathrm{Z}=1.81$ and $\mathrm{Z}=0.68)$.

The annual temperatures observed at Djelfa station during the period 1972-2016 show a significant positive trend detected by all of the statistical tests as well as the absence of long-term persistence, which confirms the magnitude of the trend (table 2). The Sen slope associated with the MK test indicates an increase of about $0.3^{\circ} \mathrm{C} /$ decade.

Table 2: Mann-Kendall Z value and sen's slope. The significant trends at the $95 \%$ confidence level are shown in bold. 


\begin{tabular}{|c|c|c|c|c|c|c|c|c|c|c|c|c|c|c|c|c|c|c|}
\hline \multirow{2}{*}{\multicolumn{2}{|c|}{$\begin{array}{l}\text { tests } \\
\text { Algiers }\end{array}$}} & Jan. & Fev. & Mar. & Apr. & Mai & Juin & Jul. & Aug. & Sep. & Oct. & Nov. & Dec. & DJF & MAM & JJA & SON & an \\
\hline & & & & & & & & & & & & & & & & & & \\
\hline \multicolumn{2}{|l|}{ Z-MK } & 1,14 & $\overline{0}, 70$ & 0,69 & 2,83 & 2,25 & 3,79 & 4,17 & 3,35 & 1,78 & 3,49 & 0,65 & 0,43 & 0,77 & 2,70 & 4,51 & 3,37 & 3,99 \\
\hline \multicolumn{2}{|l|}{ Z-PW } & 1,07 & $\overline{-}, 60$ & 0,21 & 2,20 & 2,01 & 2,87 & 3,57 & 2,83 & 1,48 & 3,15 & 0,80 & 0,39 & 0,69 & 1,42 & 3,74 & 2,68 & 2,99 \\
\hline \multicolumn{2}{|l|}{ tfpw } & 1,03 & $\overline{0}, 60$ & 0,37 & 2,82 & 2,40 & 4,10 & 4,57 & 3,67 & 1,90 & 3,64 & 0,79 & 0,31 & 0,70 & 2,87 & 5,10 & 3,46 & 4,69 \\
\hline \multicolumn{2}{|l|}{ tfpw-cu } & & & & 2,26 & 2,01 & 2,91 & 3,56 & 2,86 & 1,44 & 3,14 & & & & 1,56 & 3,80 & 2,72 & 2,97 \\
\hline \multicolumn{2}{|l|}{ mmkh } & 1,14 & $\overline{0}, 98$ & 0,72 & 2,32 & 1,97 & 3,03 & 4,91 & 3,35 & 1,32 & 2,72 & 0,65 & 0,43 & $\mathrm{NaN}$ & 1,63 & 3,68 & 2,52 & 3,04 \\
\hline \multicolumn{2}{|l|}{ MMKY } & 1,14 & $\begin{array}{l}- \\
0,77\end{array}$ & 0,59 & 2,33 & 2,10 & 3,35 & 4,01 & 3,05 & 1,55 & 3,88 & 0,67 & 0,55 & 0,78 & 1,98 & 4,13 & 2,92 & 3,13 \\
\hline \multirow[t]{3}{*}{$\begin{array}{l}\text { MK- } \\
\text { LTP }\end{array}$} & $\begin{array}{l}\mathrm{H} \\
\text { Estimate }\end{array}$ & 0,36 & 0,37 & 0,58 & 0,67 & 0,57 & 0,60 & 0,54 & 0,56 & 0,57 & 0,49 & 0,50 & 0,40 & 0,42 & 0,75 & 0,61 & 0,64 & 0,73 \\
\hline & $\begin{array}{l}\text { P-value } \\
\text { for } \mathrm{H}\end{array}$ & 0,38 & 0,43 & 0,10 & 0,01 & 0,15 & 0,06 & 0,24 & 0,15 & 0,12 & 0,58 & 0,50 & 0,71 & 0,88 & 0,00 & 0,05 & 0,03 & 0,00 \\
\hline & MK-LTP & 1,40 & $-0,84$ & 0,42 & 1,29 & 1,43 & 2,13 & 2,85 & 2,13 & 1,10 & 2,83 & 0,51 & 0,46 & 0,76 & 0,98 & 2,52 & 1,73 & 1,53 \\
\hline \multicolumn{2}{|c|}{ Sen's Slope } & 0,08 & $-0,06$ & 0,04 & 0,17 & 0,20 & 0,29 & 0,32 & 0,27 & 0,11 & 0,33 & 0,04 & 0,04 & 0,03 & 0,13 & 0,3 & 0,17 & 0,16 \\
\hline \multicolumn{19}{|l|}{ Annaba } \\
\hline \multicolumn{2}{|l|}{ Z-MK } & 1,78 & $\overline{0}, 24$ & 0,24 & 3,19 & 2,65 & 2,39 & 3,64 & 2,42 & 1,58 & 3,88 & 1,59 & 0,88 & 1,20 & 3,55 & 3,63 & 3,78 & 4,03 \\
\hline \multicolumn{2}{|l|}{ Z-PW } & 1,52 & $\overline{0}, 27$ & 0,01 & 2,21 & 2,52 & 2,37 & 3,24 & 1,87 & 1,32 & 2,92 & 1,73 & 0,71 & 0,87 & 2,15 & 2,91 & 3,10 & 2,17 \\
\hline \multicolumn{2}{|l|}{ tfpw } & 1,62 & $\overline{0}, 27$ & 0,01 & 3,01 & 2,56 & 2,60 & 3,80 & 2,62 & 1,43 & 3,92 & 1,59 & 0,54 & 0,92 & 3,27 & 3,85 & 3,97 & 4,04 \\
\hline \multicolumn{2}{|l|}{$\begin{array}{l}\text { tfpw- } \\
\mathrm{cu}\end{array}$} & & & & 2,23 & 2,50 & 2,45 & 3,27 & 1,93 & 1,32 & 2,96 & & & & 2,18 & 2,90 & 3,08 & 2,18 \\
\hline \multicolumn{2}{|l|}{ mmkh } & 1,91 & $\overline{0}, 24$ & 0,26 & 3,19 & 2,65 & 2,56 & 5,13 & 2,63 & 1,90 & 3,88 & 1,59 & 0,88 & 1,20 & 4,34 & 3,90 & 2,90 & 2,62 \\
\hline \multicolumn{2}{|l|}{ MMKY } & 1,80 & $\overline{0}, 26$ & 0,23 & 2,92 & 2,82 & 2,31 & 3,34 & 2,13 & 1,48 & 3,76 & 1,70 & 1,12 & 1,11 & 2,90 & 3,35 & 3,36 & 3,22 \\
\hline \multirow[t]{3}{*}{$\begin{array}{l}\text { MK- } \\
\text { LTP }\end{array}$} & $\begin{array}{l}\mathrm{H} \\
\text { Estimate }\end{array}$ & 0,44 & 0,44 & 0,53 & 0,56 & 0,49 & 0,57 & 0,57 & 0,60 & 0,52 & 0,54 & 0,52 & 0,38 & 0,55 & 0,66 & 0,60 & 0,62 & 0,69 \\
\hline & $\begin{array}{l}\text { P-value } \\
\text { for } \mathrm{H}\end{array}$ & 0,95 & 0,93 & 0,27 & 0,16 & 0,54 & 0,14 & 0,15 & 0,04 & 0,34 & 0,23 & 0,37 & 0,55 & 0,22 & 0,01 & 0,06 & 0,04 & 0,00 \\
\hline & MK-LTP & 1,65 & $\overline{0}, 22$ & 0,17 & 2,05 & 2,11 & 1,51 & 2,31 & 1,39 & 1,15 & 2,64 & 1,17 & 1,00 & 0,81 & 1,69 & 2,04 & 2,05 & 1,75 \\
\hline \multicolumn{2}{|c|}{ Sen's Slope } & 0,13 & - & - & 0,19 & 0,18 & 0,18 & 0,23 & 0,17 & 0,10 & 0,33 & 0,13 & 0,06 & 0,06 & 0,14 & 0,18 & 0,18 & 0,13 \\
\hline \multicolumn{19}{|l|}{ oran } \\
\hline \multicolumn{2}{|l|}{ Z-MK } & 0,75 & 0,82 & 1,33 & 3,28 & 2,40 & 3,31 & 2,67 & 2,59 & 2,19 & 3,18 & 0,23 & 0,96 & 1,21 & 3,07 & 3,23 & 2,45 & 3,69 \\
\hline \multicolumn{2}{|l|}{ Z-PW } & 0,72 & 0,78 & 0,49 & 1,83 & 1,59 & 2,40 & 2,01 & 2,00 & 1,98 & 3,01 & 0,46 & 0,82 & 1,31 & 1,49 & 2,56 & 1,93 & 1,69 \\
\hline \multicolumn{2}{|l|}{ tfpw } & 0,73 & 0,64 & 0,94 & 3,34 & 2,38 & 3,43 & 2,84 & 2,83 & 2,26 & 3,56 & 0,46 & 0,64 & 1,31 & 3,33 & 3,18 & 2,60 & 3,95 \\
\hline \multicolumn{2}{|l|}{$\begin{array}{l}\text { tfpw- } \\
\mathrm{cu}\end{array}$} & & & 0,51 & 2,03 & 1,58 & 2,50 & 2,02 & 1,95 & 1,98 & 2,95 & & & & 1,54 & 2,65 & 1,93 & 1,86 \\
\hline mmkh & & 0,75 & 1,13 & 1,33 & 3,89 & 1,27 & 2,24 & 2,85 & 2,59 & 2,52 & 2,35 & 0,23 & 0,96 & 1,12 & 1,64 & 2,18 & 2,23 & 1,98 \\
\hline MMKY & & 0,70 & 1,00 & 1,06 & 2,77 & 1,84 & 2,73 & 2,24 & 2,22 & 1,98 & 3,81 & 0,22 & 1,11 & 1,16 & 2,12 & 2,63 & 2,09 & 2,63 \\
\hline $\begin{array}{l}\text { MK- } \\
\text { LTP }\end{array}$ & $\begin{array}{l}\mathrm{H} \\
\text { Estimate }\end{array}$ & 0,50 & 0,35 & 0,67 & 0,63 & 0,72 & 0,67 & 0,64 & 0,60 & 0,58 & 0,45 & 0,50 & 0,43 & 0,47 & 0,81 & 0,66 & 0,62 & 0,80 \\
\hline & $\begin{array}{l}\text { P-value } \\
\text { for } \mathrm{H}\end{array}$ & 0,51 & 0,33 & 0,01 & 0,03 & 0,00 & 0,01 & 0,02 & 0,07 & 0,11 & 0,87 & 0,47 & 0,95 & 0,69 & 0,00 & 0,01 & 0,03 & 0,00 \\
\hline & MK-LTP & 0,59 & 1,04 & 0,62 & 1,70 & 0,96 & 1,52 & 1,35 & 1,50 & 1,33 & 2,88 & 0,18 & 0,93 & 1,03 & 0,92 & 1,52 & 1,30 & 1,17 \\
\hline Sen's Slo & & 0,06 & 0,08 & 0,08 & 0,21 & 0,18 & 0,25 & 0,19 & 0,14 & 0,13 & 0,27 & - & 0,08 & 0,07 & 0,16 & 0,18 & 0,13 & 0,14 \\
\hline
\end{tabular}


Constantine

\begin{tabular}{|c|c|c|c|c|c|c|c|c|c|c|c|c|c|c|c|c|c|c|}
\hline Z-MK & & 0,99 & $\overline{0}, 41$ & 0,73 & 2,84 & 2,31 & 2,71 & 3,51 & 2,37 & $\overline{0}, 33$ & 3,41 & 0,99 & 0,44 & 0,74 & 2,96 & 3,58 & 2,65 & 3,62 \\
\hline Z-PW & & 0,83 & $\overline{0}, 48$ & 0,49 & 2,21 & 2,20 & 2,40 & 2,97 & 1,60 & $\overline{0}, 36$ & 2,54 & 0,99 & 0,44 & 0,56 & 1,94 & 2,80 & 1,74 & 2,06 \\
\hline tfpw & & 0,73 & $\overline{-}, 43$ & 0,51 & 2,57 & 2,38 & 2,99 & 3,53 & 2,34 & $\overline{0}, 45$ & 3,43 & 0,94 & 0,37 & 0,58 & 2,71 & 3,91 & 2,70 & 3,60 \\
\hline $\begin{array}{l}\text { tfpw- } \\
\mathrm{cu}\end{array}$ & & & & & 2,25 & 2,24 & 2,38 & 2,96 & 1,75 & & 2,56 & & & & 1,89 & 2,86 & 1,79 & 2,01 \\
\hline $\mathrm{mmkh}$ & & 0,99 & $\overline{0}, 52$ & 0,81 & 3,60 & 2,77 & 2,71 & 3,65 & 2,68 & $\overline{0}, 55$ & 2,72 & 0,99 & 0,44 & 0,67 & 3,13 & 3,31 & 2,16 & 2,37 \\
\hline MMKY & & 1,12 & $\overline{0}, 46$ & 0,67 & 2,68 & 2,49 & 2,45 & 3,65 & 2,03 & $\overline{-}, 28$ & 3,17 & 1,07 & 0,55 & 0,71 & 2,53 & 3,05 & 2,09 & 2,83 \\
\hline \multirow[t]{3}{*}{$\begin{array}{l}\text { MK- } \\
\text { LTP }\end{array}$} & $\begin{array}{l}\mathrm{H} \\
\text { Estimate }\end{array}$ & 0,36 & 0,39 & 0,54 & 0,54 & 0,48 & 0,59 & 0,51 & 0,59 & 0,64 & 0,57 & 0,36 & 0,46 & 0,70 & 0,62 & 0,65 & 0,70 & 0,48 \\
\hline & $\begin{array}{l}\text { P-value } \\
\text { for } \mathrm{H}\end{array}$ & 0,38 & 0,56 & 0,24 & 0,23 & 0,63 & 0,08 & 0,38 & 0,08 & 0,02 & 0,13 & 0,37 & 0,78 & 0,00 & 0,04 & 0,02 & 0,00 & 0,62 \\
\hline & MK-LTP & 1,21 & $-0,46$ & 0,50 & 1,93 & 1,91 & 1,59 & 2,61 & 1,38 & $-0,17$ & 2,13 & 0,55 & 0,87 & 1,54 & 1,61 & 1,75 & 1,13 & 0,61 \\
\hline \multicolumn{2}{|c|}{ Sen's Slope } & 0,1 & $-0,05$ & 0,07 & 0,26 & 0,27 & 0,31 & 0,29 & 0,2 & $-0,03$ & 0,37 & 0,09 & 0,04 & 0,05 & 0,2 & 0,27 & 0,15 & 0,16 \\
\hline \multicolumn{19}{|l|}{ Mascara } \\
\hline Z-MK & & 1,22 & $\overline{1,31}$ & 1,82 & 2,75 & 3,70 & 3,69 & 2,98 & 3,06 & 1,41 & 3,23 & 1,02 & 0,37 & $\overline{-}, 01$ & 3,86 & 4,07 & 2,80 & 4,42 \\
\hline Z-PW & & 1,16 & $\overline{1,23}$ & 0,63 & 2,42 & 2,83 & 2,15 & 1,86 & 1,55 & 1,02 & 2,69 & 0,80 & 0,75 & 0,12 & 2,58 & 2,10 & 1,84 & 2,01 \\
\hline tfpw & & 1,14 & $\overline{1,14}$ & 1,33 & 2,95 & 3,48 & 3,65 & 2,61 & 2,81 & 1,50 & 3,24 & 0,80 & 0,58 & 0,12 & 3,73 & 3,77 & 2,56 & 4,35 \\
\hline $\begin{array}{l}\text { tfpw- } \\
\mathrm{cu}\end{array}$ & & & & 0,60 & 2,37 & 2,71 & 2,08 & 1,84 & 1,38 & 0,82 & 2,69 & & & & 2,69 & 1,98 & 1,94 & 2,10 \\
\hline mmkh & & 1,23 & $\overline{1,31}$ & 1,41 & 4,55 & 3,70 & 3,21 & 4,96 & 3,06 & 1,71 & 2,81 & 1,02 & 0,37 & $\overline{0}, 02$ & 3,86 & 3,33 & 2,18 & 3,49 \\
\hline MMKY & & 1,28 & $\overline{1,50}$ & 1,38 & 2,71 & 4,07 & 3,09 & 2,83 & 2,49 & 1,13 & 3,90 & 1,01 & 0,59 & $\overline{0}, 01$ & 3,72 & 3,61 & 2,59 & 3,48 \\
\hline \multirow[t]{3}{*}{$\begin{array}{l}\text { MK- } \\
\text { LTP }\end{array}$} & $\begin{array}{l}\mathrm{H} \\
\text { Estimate }\end{array}$ & 0,33 & 0,22 & 0,76 & 0,36 & 0,28 & 0,63 & 0,50 & 0,66 & 0,64 & 0,43 & 0,42 & 0,20 & 0,45 & 0,37 & 0,52 & 0,56 & 0,70 \\
\hline & $\begin{array}{l}\text { P-value } \\
\text { for } \mathrm{H}\end{array}$ & 0,56 & 0,13 & 0,00 & 0,75 & 0,30 & 0,05 & 0,40 & 0,02 & 0,04 & 0,79 & 0,84 & 0,08 & 0,66 & 0,78 & 0,29 & 0,16 & 0,01 \\
\hline & MK-LTP & 1,42 & $-2,18$ & 0,65 & 2,90 & 5,11 & 1,81 & 2,11 & 1,38 & 0,68 & 2,77 & 0,89 & 0,68 & $-0,01$ & 4,01 & 2,68 & 1,65 & 1,81 \\
\hline \multicolumn{2}{|c|}{ Sen's Slope } & 0,22 & $-0,26$ & 0,25 & 0,54 & 0,92 & 0,74 & 0,78 & 0,61 & 0,25 & 0,67 & 0,2 & 0,07 & - & 0,55 & 0,67 & 0,38 & 0,42 \\
\hline \multicolumn{19}{|l|}{ Djelfa } \\
\hline Z-MK & & 1,41 & $\overline{0}, 05$ & 2,15 & 2,58 & 2,18 & 1,14 & 4,17 & 4,07 & 1,51 & 3,40 & 0,80 & 0,58 & 0,69 & 2,97 & 3,79 & 3,70 & 4,14 \\
\hline Z-PW & & 1,12 & $\overline{0}, 03$ & 1,97 & 2,34 & 1,75 & 0,84 & 3,66 & 2,91 & 1,04 & 2,86 & 0,90 & 0,29 & 0,39 & 1,99 & 2,63 & 2,22 & 2,17 \\
\hline tfpw & & 1,00 & $\overline{0}, 03$ & 2,38 & 2,24 & 1,91 & 0,86 & 4,10 & 3,87 & 1,12 & 3,31 & 0,98 & 0,23 & 0,39 & 2,58 & 3,49 & 3,35 & 3,77 \\
\hline $\begin{array}{l}\text { tfpw- } \\
\mathrm{cu}\end{array}$ & & & & & 2,76 & & & 3,40 & 3,01 & & 2,57 & 1,04 & & & 2,16 & 2,63 & 2,07 & 2,20 \\
\hline mmkh & & 1,41 & $\overline{0}, 11$ & 2,15 & 2,58 & 2,18 & 1,14 & 9,69 & 4,07 & 1,65 & 2,73 & 0,80 & 0,58 & $\mathrm{NaN}$ & 2,98 & 3,79 & 3,70 & 4,14 \\
\hline MMKY & & 1,76 & $\overline{-}$ & 1,87 & 2,73 & 2,38 & 1,10 & 8,16 & 4,29 & 1,55 & 3,99 & 0,75 & 0,72 & 0,69 & 3,17 & 3,93 & 3,48 & 3,77 \\
\hline \multirow[t]{3}{*}{$\begin{array}{l}\text { MK- } \\
\text { LTP }\end{array}$} & $\begin{array}{l}\mathrm{H} \\
\text { Estimate }\end{array}$ & 0,28 & 0,36 & 0,62 & 0,50 & 0,25 & 0,54 & 0,20 & 0,45 & 0,38 & 0,41 & 0,56 & 0,31 & 0,49 & 0,32 & 0,47 & 0,56 & 0,56 \\
\hline & $\begin{array}{l}\text { P-value } \\
\text { for } \mathrm{H}\end{array}$ & 0,25 & 0,67 & 0,05 & 0,41 & 0,16 & 0,22 & 0,06 & 0,69 & 0,80 & 0,97 & 0,16 & 0,34 & 0,47 & 0,42 & 0,60 & 0,17 & 0,16 \\
\hline & MK-LTP & 1,99 & $\overline{0}, 05$ & 1,09 & 1,86 & 3,40 & 0,72 & 7,73 & 3,36 & 1,55 & 3,15 & 0,48 & 0,76 & 0,52 & 3,70 & 3,00 & 2,25 & 2,50 \\
\hline
\end{tabular}




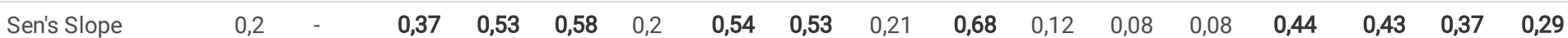

On a seasonal scale, the MK test does not show a significant temperature trend in winter, unlike spring and summer which are marked by a positive trend and register an increase of $0.44,0.4^{\circ} \mathrm{C} /$ decade respectively. In autumn, all the tests show a positive trend in temperatures as well as the absence of long-term persistence $(Z=2.25)$ which shows the intensity of the warming during this season in the region of Djelfa. The Sen slope associated with the MK test indicates an increase of $0.37^{\circ} \mathrm{C} /$ decade.

On a monthly scale, all temperature time series are not autocorrelated. The MK test indicates that there is no significant trend in January, February, June, September, November and December. Analysis of temperatures in the months of March, April and May shows a significant positive trend which reflects respectively into an increase of $0.4^{\circ} \mathrm{C}, 0.53$ and $0.6^{\circ} \mathrm{C} /$ decade. The temperatures in July and August also shows a significant positive trend which reproduces respectively into an increase of 0.54 and $0.53^{\circ} \mathrm{C} /$ decade. The month of October is distinguished, as for the other stations, by a significant rise in temperatures of around $0.7^{\circ} \mathrm{C} /$ decade.

\subsection{Identification of change point}

The statistical Pettitt test (1979) is used to detect a change point in mean values of statistical series and thus identify the date of the change. However, when the time series data is autocorrelated, it becomes necessary to apply the modified Pettitt test based on the TFPW-cu approach developed by Sérinaldi and Kilsby (2016). If the autocorrelated time series of temperature at a given time scale presented a change point using the original Pettitt's test, the Pettitt test using TFPWcu will be subsequently used.

The modified Pettitt test using TFPWcu consists in splitting the initial series into two sub-series based on the change point obtained from original Pettitt's test and computed the difference of the means $(\Delta)$ of the two sub-series, lag-1 autocorrelation coefficient $\hat{\rho}$ after elimination of point change, first stage corrected $\rho_{K}^{*}$ coefficients and finally, the second stage corrected $\left(\hat{\rho}^{*}\right)$ lag-1 autocorrelation coefficient. Table 3 shows values before and after removing autocorrelation of test statistic $\mathrm{K}_{\mathrm{T}}$, year in which change point was appeared and p-value and the parameters of Pettitt test using TFPWcu ( ${ }^{\Delta, \hat{\rho}}, \rho_{K}^{*}$ and $\hat{\rho}^{*}$ )

At the Algiers meteorological station, it is found that the significance of the Pettitt test at the different time scale agrees perfectly with the results of the Mann-Kendall test. Using the Pettitt test, the annual temperature has change point in the year $1984\left(+0.9^{\circ} \mathrm{C}\right)$ with an increase of $0.9^{\circ} \mathrm{C}(\mathrm{p}-\mathrm{value}<0.0001)$, while for seasonal time scales, spring, summer and autumn data series have reflected a shift respectively in the year $1986\left(+0.9^{\circ} \mathrm{C}\right), 1981\left(+1.5^{\circ} \mathrm{C}\right)$ and $1982(+1.1$ ${ }^{\circ} \mathrm{C}$ ) and all having p-values less than 0.0001 . Winter season has not detected any change point at $5 \%$ significance level. After corrected and unbiased trend free prewhitening (TFPWcu), the annual, spring, summer and autumn temperature series were tested again for shift using Pettitt's test. The results showed that, in principle, all KT values are decreased (table 3), while the p-values are increased relative to original Pettitt's test but there always remains significative (p-values <0.05). Thus, change point is affirmed in the same years 1984, 1981 and 1982, by modified Pettitt test using TFPWcu, for respectively annual, summer and autumn temperatures series. For the spring temperature data, the date of change point has been brought backward by one year (1985) compared with the original Pettitt's test.

Analysis of monthly temperatures series using original Pettitt test shows no break in time series of January, February, Mars, November and December. An increase of temperature that exceeds $1^{\circ} \mathrm{C}$ is observed from April to October early 80 's (except April) and reached $1.7^{\circ} \mathrm{C}$ in July, August and October. The Pvalue is less than 0.0001. After using TFPWcu approach, the temperature series of April, June, July and August were tested again for shift using Pettitt's test. The results showed that all KT values are decreased (table 3), while the p-values are increased comparatively to original Pettitt's test but there always remains significative ( $p$-values $<0.05$ ). The date of change point detected by modified Pettitt test is affirmed in the same years, except on June, where, the date of change point has been brought forward by three years (1984) compared with the original Pettitt's test.

Analysis of temperature time series of Annaba station using original Pettitt test shown that the annual temperature has change point in the year 1980 with an increase of $0.8^{\circ} \mathrm{C}$ ( $\mathrm{p}$-value $<0.0001$ ), while for seasonal time scales, spring, summer and autumn data series have reflected a shift respectively in the year $1980\left(+0.7^{\circ} \mathrm{C}\right), 1981\left(+1.1^{\circ} \mathrm{C}\right)$ and $1980\left(+1.1^{\circ} \mathrm{C}\right)$ and all having p-values less than 0.0001 . Winter season has not detected any change point at $5 \%$ significance level. After corrected and unbiased trend free prewhitening (TFPWcu), the annual, spring, summer and autumn temperature series were tested again for shift using Pettitt's test. The results showed that all KT values are decreased (table 3), while the p-values are slightly increased relative to original Pettitt's test but there always remains significative ( $p$-values $<0.05$ ). For the change point, it is confirmed in the same years as that found by original Pettitt test.

Analysis of monthly temperatures series using original Pettitt test shows no trend in time series of January, February, Mars and December, while a break point is observed in April $\left(+0,9^{\circ} \mathrm{C}\right)$, May $\left(+1,1^{\circ} \mathrm{C}\right)$, June $\left(+0,9^{\circ} \mathrm{C}\right)$, July $\left(+1,3^{\circ} \mathrm{C}\right)$, August $\left(+1,1^{\circ} \mathrm{C}\right)$, September $\left(+0,8^{\circ} \mathrm{C}\right)$, October $\left(+1,7^{\circ} \mathrm{C}\right)$ and November $\left(+0,8^{\circ} \mathrm{C}\right)$ respectively at the date $1980,1992,1992,1981,1985,1980,1985$ and 1982 . The P-value is generally less than 0.0001 except for September ( 0.02$)$. After using TFPWcu approach, the temperature series of August and October were tested again for shift using Pettitt's test. The results showed that $\mathrm{K}_{\mathrm{T}}$ values are decreased (table 3 ) but p-values remains significative ( $p$-values=0.00). The date of change point detected by modified Pettitt test is affirmed in the same years in August, while, the date of change point has been brought backward by one year (1984) compared with the original Pettitt's test.

Table 3: Change point for Original and Modified Pettitt's test 


\begin{tabular}{|c|c|c|c|c|c|c|c|c|c|c|c|c|c|c|c|}
\hline \multirow[t]{2}{*}{ stations } & \multirow[t]{2}{*}{$\begin{array}{l}\text { time } \\
\text { séries }\end{array}$} & \multicolumn{3}{|c|}{ Original Pettitt test } & \multicolumn{8}{|c|}{ Modified Pettitt test using TFPWcu } & \multicolumn{3}{|c|}{$\begin{array}{l}\text { Difference of temperature } \\
\left({ }^{\circ} \mathrm{C}\right)\end{array}$} \\
\hline & & $\mathrm{Kt}$ & Year & $P$-value & $\underset{(\mathrm{mm})}{\Delta}$ & $\rho^{\wedge}$ & $\rho_{k}^{*}$ & $\rho^{\wedge *}$ & $\rho$ & Kt & Year & $\begin{array}{l}\mathrm{P} \text { - } \\
\text { value }\end{array}$ & $\begin{array}{l}\mathrm{T}^{\circ} \mathrm{C} \\
\text { Before }\end{array}$ & $\begin{array}{l}\mathrm{T}^{\circ} \mathrm{C} \\
\text { after }\end{array}$ & $\neq$ \\
\hline \multirow[t]{17}{*}{ Algiers } & Jan. & 195 & $\begin{array}{l}\text { no } \\
\text { break }\end{array}$ & 0,73 & & & & & & & & & & & \\
\hline & Fev. & 231 & $\begin{array}{l}\text { no } \\
\text { break }\end{array}$ & 0,54 & & & & & & & & & & & \\
\hline & Mar. & 315 & $\begin{array}{l}\text { no } \\
\text { break }\end{array}$ & 0,19 & & & & & & & & & & & \\
\hline & Apr. & 567 & 1995 & 0,00 & $-1,00$ & 0,29 & 0,31 & 0,30 & $-0,07$ & 491 & 1995 & 0,01 & 14,7 & 15,8 & 1,1 \\
\hline & Mai & 564 & 1987 & 0,00 & $-1,06$ & 0,13 & 0,15 & 0,14 & $-0,01$ & 513 & 1985 & 0,01 & 17,7 & 18,8 & 1,1 \\
\hline & Juin & 677 & 1981 & <,0001 & $-1,27$ & 0,28 & 0,29 & 0,29 & $-0,07$ & 530 & 1984 & 0,00 & 21,3 & 22,6 & 1,3 \\
\hline & Jul & 764 & 1981 & $<0,0001$ & $-1,49$ & 0,26 & 0,28 & 0,27 & $-0,01$ & 645 & 1981 & 0,00 & 24,1 & 25,7 & 1,7 \\
\hline & Aug & 766 & 1985 & $<, 0001$ & $-1,51$ & 0,24 & 0,26 & 0,25 & 0,06 & 595 & 1985 & 0,00 & 25,0 & 26,6 & 1,7 \\
\hline & Sep. & 482 & 1985 & 0,01 & $-0,90$ & 0,19 & 0,20 & 0,20 & $-0,01$ & 406 & 1985 & 0,04 & 23,0 & 23,9 & 1,0 \\
\hline & Oct. & 662 & 1984 & $<0,0001$ & $-1,57$ & 0,10 & 0,12 & 0,11 & $-0,18$ & 647 & 1984 & $\dot{0}, 0001$ & 18,9 & 20,6 & 1,7 \\
\hline & Nov. & 304 & $\begin{array}{l}\text { no } \\
\text { break }\end{array}$ & 0,23 & & & & & & & & & & & \\
\hline & Dec. & 218 & $\begin{array}{l}\text { no } \\
\text { break }\end{array}$ & 0,61 & & & & & & & & & & & \\
\hline & DJF & 232 & $\begin{array}{l}\text { no } \\
\text { break }\end{array}$ & 0,56 & & & & & & & & & & & \\
\hline & MAM & 652 & 1986 & 0,00 & $-0,78$ & 0,46 & 0,49 & 0,47 & 0,01 & 437 & 1985 & 0,03 & 15,1 & 16,0 & 0,9 \\
\hline & JJA & 858 & 1981 & <,0001 & $-1,33$ & 0,33 & 0,35 & 0,34 & 0,00 & 661 & 1981 & 0,00 & 23,4 & 24,9 & 1,5 \\
\hline & SON & 821 & 1982 & $\begin{array}{l}<, 0001 \\
0,00\end{array}$ & $-1,02$ & 0,30 & 0,32 & 0,31 & $-0,19$ & 626 & 1982 & $<, 0001$ & 18,9 & 20,0 & 1,1 \\
\hline & an & 834 & 1984 & $\begin{array}{l}<, 0001 \\
0,0\end{array}$ & $-0,78$ & 0,46 & 0,48 & 0,47 & $-0,15$ & 624 & 1984 & 0,00 & 17,3 & 18,2 & 0,9 \\
\hline \multirow[t]{13}{*}{ Annaba } & Jan. & 300 & $\begin{array}{l}\text { no } \\
\text { break }\end{array}$ & 0,23 & & & & & & & & & & & \\
\hline & Fev. & 181 & $\begin{array}{l}\text { no } \\
\text { break }\end{array}$ & 0,81 & & & & & & & & & & & \\
\hline & Mar. & 280 & $\begin{array}{l}\text { no } \\
\text { break }\end{array}$ & 0,30 & & & & & & & & & & & \\
\hline & Apr. & 608 & 1980 & 0,00 & $-0,9$ & 0,21 & 0,23 & 0,23 & $-0,05$ & 494 & 1980 & 0,01 & 14,6 & 15,5 & 0,9 \\
\hline & Mai & 527 & 1992 & 0,00 & $-1,0$ & 0,07 & 0,09 & 0,08 & 0,00 & 503 & 1992 & 0,01 & 17,8 & 18,9 & 1,1 \\
\hline & Juin & 506 & 1992 & 0,00 & $-0,9$ & 0,10 & 0,12 & 0,11 & 0,04 & 491 & 1987 & 0,01 & 21,3 & 22,2 & 0,9 \\
\hline & Jul & 732 & 1981 & $<0,0001$ & $-1,2$ & 0,20 & 0,22 & 0,21 & $-0,10$ & 619 & 1981 & 0,00 & 23,8 & 25,1 & 1,3 \\
\hline & Aug & 662 & 1985 & <,0001 & $-1,1$ & 0,22 & 0,24 & 0,24 & 0,13 & 533 & 1985 & 0,00 & 24,9 & 26,0 & 1,1 \\
\hline & Sep. & 447 & 1980 & 0,02 & $-0,7$ & 0,10 & 0,11 & 0,11 & 0,02 & 394 & $\begin{array}{l}\text { no } \\
\text { break }\end{array}$ & 0,06 & 23,0 & 23,8 & 0,8 \\
\hline & Oct. & 699 & 1985 & $<0,0001$ & $-1,6$ & 0,23 & 0,25 & 0,24 & $-0,13$ & 564 & 1984 & 0,00 & 19,2 & 20,9 & 1,7 \\
\hline & Nov. & 450 & 1982 & 0,02 & no break & & & & & & & & 15,2 & 16,1 & 0,8 \\
\hline & Dec. & 235 & $\begin{array}{l}\text { no } \\
\text { break }\end{array}$ & 0,52 & & & & & & & & & & & \\
\hline & DJF & 324 & $\begin{array}{l}\text { no } \\
\text { break }\end{array}$ & 0,19 & & & & & & & & & & & \\
\hline
\end{tabular}




\begin{tabular}{|c|c|c|c|c|c|c|c|c|c|c|c|c|c|c|c|}
\hline & MAM & 690 & 1980 & $<, 0001$ & $-0,7$ & 0,36 & 0,38 & 0,37 & 0,04 & 452 & 1980 & 0,02 & 15,1 & 15,8 & 0,7 \\
\hline & JJA & 815 & 1981 & $<, 0001$ & $-1,0$ & 0,24 & 0,26 & 0,25 & 0,02 & 633 & 1981 & $\begin{array}{l}< \\
0,0001\end{array}$ & 23,3 & 24,4 & 1,1 \\
\hline & SON & 811 & 1980 & $\begin{array}{l}<, 0001 \\
0,\end{array}$ & $-1,0$ & 0,28 & 0,30 & 0,29 & $-0,15$ & 620 & 1980 & 0,00 & 19,1 & 20,2 & 1,1 \\
\hline & an & 879 & 1980 & $\begin{array}{l}<, 0001 \\
0,\end{array}$ & $-0,7$ & 0,45 & 0,47 & 0,45 & $-0,10$ & 558 & 1980 & 0,00 & 17,3 & 18,1 & 0,8 \\
\hline \multirow[t]{17}{*}{ Oran } & Jan. & 244 & $\begin{array}{l}\text { no } \\
\text { break }\end{array}$ & 0,48 & & & & & & & & & & & \\
\hline & Fev. & 180 & $\begin{array}{l}\text { no } \\
\text { break }\end{array}$ & 0,81 & & & & & & & & & & & \\
\hline & Mar. & 442 & 1986 & 0,02 & $-0,7$ & 0,28 & 0,30 & 0,29 & 0,05 & 284 & $\begin{array}{l}\text { no } \\
\text { break }\end{array}$ & 0,29 & & & \\
\hline & Apr. & 592 & 1994 & 0,00 & $-1,1$ & 0,31 & 0,33 & 0,32 & $-0,03$ & 449 & 1991 & 0,02 & 15,3 & 16,5 & 1,1 \\
\hline & Mai & 554 & 1991 & 0,00 & $-1,1$ & 0,35 & 0,37 & 0,36 & $-0,05$ & 438 & 1991 & 0,02 & 18,4 & 19,6 & 1,2 \\
\hline & Juin & 661 & 1995 & $<, 0001$ & $-1,3$ & 0,32 & 0,34 & 0,33 & 0,02 & 526 & 1992 & 0,00 & 21,8 & 23,1 & 1,3 \\
\hline & Jul & 588 & 1993 & 0,00 & $-1,1$ & 0,29 & 0,30 & 0,30 & 0,03 & 457 & 1997 & 0,01 & 24,8 & 26,1 & 1,2 \\
\hline & Aug & 687 & 1985 & $\begin{array}{l}<, 0001 \\
0,0\end{array}$ & $-1,1$ & 0,26 & 0,28 & 0,27 & 0,05 & 499 & 1985 & 0,01 & 25,3 & 26,5 & 1,2 \\
\hline & Sep. & 422 & 1982 & 0,03 & $-0,6$ & 0,11 & 0,13 & 0,13 & $-0,08$ & 390 & $\begin{array}{l}\text { no } \\
\text { break }\end{array}$ & 0,06 & 23,1 & 23,7 & 0,6 \\
\hline & Oct. & 553 & 1984 & 0,00 & $-1,2$ & 0,03 & 0,05 & 0,05 & $-0,16$ & 557 & 1984 & 0,00 & 18,9 & 20,2 & 1,2 \\
\hline & Nov. & 234 & $\begin{array}{l}\text { no } \\
\text { break }\end{array}$ & 0,52 & & & & & & & & & & & \\
\hline & Dec. & 300 & $\begin{array}{l}\text { no } \\
\text { break }\end{array}$ & 0,23 & & & & & & & & & & & \\
\hline & DJF & 326 & $\begin{array}{l}\text { no } \\
\text { break }\end{array}$ & 0,19 & & & & & & & & & & & \\
\hline & MAM & 700 & 1993 & $\begin{array}{l}<, 0001 \\
0,\end{array}$ & $-0,9$ & 0,57 & 0,59 & 0,57 & 0,04 & 405 & 1991 & 0,04 & 15,8 & 16,9 & 1,1 \\
\hline & JJA & 736 & 1988 & $\begin{array}{l}<, 0001 \\
0,0\end{array}$ & $-1,0$ & 0,37 & 0,39 & 0,38 & 0,05 & 514 & 1988 & 0,00 & 24,0 & 25,1 & 1,1 \\
\hline & SON & 597 & 1982 & 0,00 & $-0,8$ & 0,25 & 0,27 & 0,26 & $-0,12$ & 484 & 1982 & 0,01 & 18,9 & 19,8 & 0,9 \\
\hline & an & 749 & 1986 & $\begin{array}{l}<, 0001 \\
0,0\end{array}$ & $-0,5$ & 0,55 & 0,57 & 0,56 & $-0,09$ & 429 & 1993 & 0,03 & 17,6 & 18,5 & 0,8 \\
\hline \multirow[t]{12}{*}{ Constantine } & Jan. & 240 & $\begin{array}{l}\text { no } \\
\text { break }\end{array}$ & 0,49 & & & & & & & & & & & \\
\hline & Fev. & 188 & $\begin{array}{l}\text { no } \\
\text { break }\end{array}$ & 0,77 & & & & & & & & & & & \\
\hline & Mar. & 345 & $\begin{array}{l}\text { no } \\
\text { break }\end{array}$ & 0,13 & & & & & & & & & & & \\
\hline & Apr. & 499 & 1997 & 0,01 & $-1,44$ & 0,13 & 0,15 & 0,14 & $-0,11$ & 466 & 1996 & 0,01 & 12,3 & 13,7 & 1,4 \\
\hline & Mai & 497 & 1992 & 0,01 & $-1,62$ & 0,02 & 0,03 & 0,03 & $-0,02$ & 502 & 1992 & 0,01 & 16,5 & 18,2 & 1,7 \\
\hline & Juin & 559 & 1992 & 0,00 & $-1,71$ & 0,20 & 0,22 & 0,21 & $-0,04$ & 484 & 1992 & 0,01 & 21,5 & 23,4 & 1,9 \\
\hline & Jul & 709 & 1981 & $\begin{array}{l}<, 0001 \\
0,0\end{array}$ & $-1,53$ & 0,13 & 0,15 & 0,15 & $-0,02$ & 601 & 1981 & 0,00 & 24,8 & 26,5 & 1,6 \\
\hline & Aug & 602 & 1985 & 0,00 & $-1,21$ & 0,23 & 0,25 & 0,24 & 0,14 & 449 & 1985 & 0,02 & 25,1 & 26,3 & 1,2 \\
\hline & Sep. & 286 & $\begin{array}{l}\text { no } \\
\text { break }\end{array}$ & 0,27 & & & & & & & & & & & \\
\hline & Oct. & 671 & 1985 & $\begin{array}{l}<, 0001 \\
0,0\end{array}$ & $-1,88$ & 0,23 & 0,25 & 0,24 & $-0,17$ & 547 & 1985 & 0,00 & 16,0 & 18,0 & 2,0 \\
\hline & Nov. & 337 & $\begin{array}{l}\text { no } \\
\text { break }\end{array}$ & 0,14 & & & & & & & & & & & \\
\hline & Dec. & 184 & no & 0,79 & & & & & & & & & & & \\
\hline
\end{tabular}


break

\begin{tabular}{|c|c|c|c|c|c|c|c|c|c|c|c|c|c|c|}
\hline DJF & 224 & $\begin{array}{l}\text { no } \\
\text { break }\end{array}$ & 0,60 & & & & & & & & & & & \\
\hline MAM & 601 & 1993 & 0,00 & $-1,13$ & 0,27 & 0,29 & 0,28 & $-0,06$ & 435 & 1993 & 0,02 & 12,9 & 14,1 & 1,2 \\
\hline JJA & 801 & 1981 & $\begin{array}{l}<, 0001 \\
0\end{array}$ & $-1,38$ & 0,34 & 0,36 & 0,35 & 0,03 & 555 & 1981 & 0,00 & 23,7 & 25,3 & 1,5 \\
\hline SON & 681 & 1986 & $\begin{array}{l}<, 0001 \\
0\end{array}$ & $-1,02$ & 0,34 & 0,36 & 0,35 & $-0,13$ & 432 & 1986 & 0,03 & 16,3 & 17,4 & 1,1 \\
\hline an & 757 & 1984 & $\begin{array}{l}<, 0001 \\
0,\end{array}$ & $-0,83$ & 0,43 & 0,45 & 0,43 & $-0,15$ & 496 & 1984 & 0,01 & 15,2 & 16,1 & 0,9 \\
\hline
\end{tabular}

\begin{tabular}{|c|c|c|c|c|c|c|c|c|c|c|c|c|c|c|c|}
\hline \multirow[t]{17}{*}{ Mascara } & Jan. & 130 & $\begin{array}{l}\text { no } \\
\text { break }\end{array}$ & 0,26 & & & & & & & & & & & \\
\hline & Fev. & 111 & $\begin{array}{l}\text { no } \\
\text { break }\end{array}$ & 0,44 & & & & & & & & & & & \\
\hline & Mar. & 190 & 1988 & 0,03 & $-0,99$ & 0,39 & 0,43 & 0,40 & 0,23 & 114 & $\begin{array}{l}\text { no } \\
\text { break }\end{array}$ & 0,41 & 11,4 & 12,46 & 1,1 \\
\hline & Apr. & 188 & 1996 & 0,03 & $-1,19$ & 0,14 & 0,17 & 0,16 & 0,05 & 166 & $\begin{array}{l}\text { no } \\
\text { break }\end{array}$ & 0,08 & 13,8 & 15 & 1,2 \\
\hline & Mai & 224 & 1993 & 0,01 & $-1,91$ & 0,20 & 0,23 & 0,22 & $-0,03$ & 184 & 1991 & 0,04 & 17,2 & 19,1 & 1,9 \\
\hline & Juin & 268 & 1997 & 0,00 & $-1,95$ & 0,39 & 0,42 & 0,40 & $-0,16$ & 174 & $\begin{array}{l}\text { no } \\
\text { break }\end{array}$ & 0,06 & 22,1 & 24,03 & 1,9 \\
\hline & Jul & 222 & 1997 & 0,01 & $-1,68$ & 0,28 & 0,31 & 0,29 & 0,09 & 164 & $\begin{array}{l}\text { no } \\
\text { break }\end{array}$ & 0,08 & 25,9 & 27,6 & 1,7 \\
\hline & Aug & 227 & 1985 & 0,00 & $-2,30$ & 0,40 & 0,43 & 0,41 & 0,10 & 124 & $\begin{array}{l}\text { no } \\
\text { break }\end{array}$ & 0,32 & 25,07 & 27,38 & 2,3 \\
\hline & Sep. & 101 & $\begin{array}{l}\text { no } \\
\text { break }\end{array}$ & 0,56 & $-1,40$ & 0,27 & 0,30 & 0,29 & $-0,09$ & 82 & $\begin{array}{l}\text { no } \\
\text { break }\end{array}$ & 0,78 & & & \\
\hline & Oct. & 224 & 1998 & 0,01 & $-1,83$ & 0,07 & 0,10 & 0,10 & $-0,23$ & 208 & 1998 & 0,01 & 17,8 & 19,5 & 1,8 \\
\hline & Nov. & 118 & $\begin{array}{l}\text { no } \\
\text { break }\end{array}$ & 0,37 & & & & & & & & & & & \\
\hline & Dec. & 64 & $\begin{array}{l}\text { no } \\
\text { break }\end{array}$ & 0,94 & & & & & & & & & & & \\
\hline & DJF & 67 & $\begin{array}{l}\text { no } \\
\text { break }\end{array}$ & 0,95 & & & & & & & & & & & \\
\hline & MAM & 268 & 1996 & 0,00 & $-1,19$ & 0,36 & 0,39 & 0,37 & 0,10 & 180 & 1992 & 0,04 & 14,2 & 15,5 & 1,3 \\
\hline & JJA & 292 & 1997 & 0,00 & $-1,61$ & 0,42 & 0,45 & 0,43 & 0,02 & 176 & $\begin{array}{l}\text { no } \\
\text { break }\end{array}$ & 0,06 & 24,76 & 26,37 & 1,6 \\
\hline & SON & 193 & 2000 & 0,04 & $-0,86$ & 0,22 & 0,25 & 0,24 & $-0,22$ & 150 & $\begin{array}{l}\text { no } \\
\text { break }\end{array}$ & 0,14 & 17,87 & 18,73 & 0,9 \\
\hline & an & 260 & 1996 & 0,00 & $-0,88$ & 0,55 & 0,59 & 0,56 & $-0,12$ & 160 & $\begin{array}{l}\text { no } \\
\text { break }\end{array}$ & 0,10 & 16,62 & 17,49 & 0,9 \\
\hline
\end{tabular}

$\begin{array}{llll}\text { Djelfa Jan. } \quad 149 & \begin{array}{l}\text { no } \\ \text { break }\end{array} & 0,24\end{array}$

\begin{tabular}{|c|c|c|c|c|c|c|c|c|c|c|c|c|c|c|}
\hline Fev. & 103 & $\begin{array}{l}\text { no } \\
\text { break }\end{array}$ & 0,66 & & & & & & & & & & & \\
\hline Mar. & 195 & 1999 & 0,04 & & & & & & & & & 8,4 & 9,6 & 1,2 \\
\hline Apr. & 206 & 1982 & 0,04 & $-1,56$ & 0,03 & 0,06 & 0,05 & $-0,22$ & 198 & $\begin{array}{l}\text { no } \\
\text { break }\end{array}$ & 0,06 & 10,92 & 12,5 & 1,6 \\
\hline
\end{tabular}

\begin{tabular}{|c|c|c|c|c|c|c|c|c|c|c|c|c|c|c|}
\hline Mai & 169 & $\begin{array}{l}\text { no } \\
\text { break }\end{array}$ & 0,13 & & & & & & & & & & & \\
\hline Juin & 150 & $\begin{array}{l}\text { no } \\
\text { break }\end{array}$ & 0,24 & & & & & & & & & & & \\
\hline Jul & 279 & 1992 & 0,00 & $-1,36$ & 0,05 & 0,07 & 0,07 & $-0,16$ & 275 & 1992 & 0,00 & 25,6 & 26,9 & 1,3 \\
\hline Aug & 278 & 1985 & 0,00 & $-1,40$ & 0,25 & 0,28 & 0,27 & $-0,12$ & 208 & 1985 & 0,05 & 24,5 & 26,0 & 1,4 \\
\hline Sep. & 170 & $\begin{array}{l}\text { no } \\
\text { break }\end{array}$ & 0,13 & & & & & & & & & & & \\
\hline
\end{tabular}




\begin{tabular}{|c|c|c|c|c|c|c|c|c|c|c|c|c|c|c|}
\hline Oct. & 233 & 1998 & 0,01 & $-2,05$ & 0,13 & 0,15 & 0,15 & $-0,09$ & 236 & 1998 & 0,02 & 14,4 & 16,2 & 1,9 \\
\hline Nov. & 188 & $\begin{array}{l}\text { no } \\
\text { break }\end{array}$ & 0,07 & $-1,31$ & 0,08 & 0,11 & 0,10 & $-0,02$ & 189 & 1982 & 0,09 & & & \\
\hline Dec. & 106 & $\begin{array}{l}\text { no } \\
\text { break }\end{array}$ & 0,63 & & & & & & & & & & & \\
\hline DJF & 142 & $\begin{array}{l}\text { no } \\
\text { break }\end{array}$ & 0,41 & & & & & & & & & & & \\
\hline MAM & 255 & 1985 & 0,02 & $-1,23$ & 0,14 & 0,17 & 0,16 & $-0,24$ & 200 & $\begin{array}{l}\text { no } \\
\text { break }\end{array}$ & 0,06 & 11,8 & 13,0 & 1,2 \\
\hline JJA & 336 & 1992 & 0,00 & $-1,14$ & 0,22 & 0,25 & 0,24 & $-0,10$ & 238 & 1992 & 0,01 & 24,1 & 25,3 & 1,2 \\
\hline SON & 282 & 1998 & 0,00 & $-0,90$ & 0,29 & 0,32 & 0,31 & $-0,07$ & 164 & $\begin{array}{l}\text { no } \\
\text { break }\end{array}$ & 0,19 & 14,73 & 15,63 & 0,9 \\
\hline an & 294 & 1993 & 0,00 & $-0,77$ & 0,40 & 0,43 & 0,41 & $-0,12$ & 194 & $\begin{array}{l}\text { no } \\
\text { break }\end{array}$ & 0,08 & 14,17 & 14,93 & 0,8 \\
\hline
\end{tabular}

Analysis of temperature time series of Oran station using original Pettitt test shown that the annual temperature has change point in the year 1986 with an increase of $0.8^{\circ} \mathrm{C}$ ( $\mathrm{p}$-value $<0.0001$ ), while for seasonal time scales, spring, summer and autumn data series have reflected a shift respectively in the year $1993\left(+1.1^{\circ} \mathrm{C}\right), 1988\left(+1.1^{\circ} \mathrm{C}\right)$ and $1982\left(+0.9^{\circ} \mathrm{C}\right)$ and all having $\mathrm{p}$-values less than 0.0001 . Winter season has not detected any change point at $5 \%$ significance level. After using TFPW ${ }_{\mathrm{cu}}$ approach, it is found that all $\mathrm{KT}$ values are decreased (table $\mathrm{xx}$ ), while the p-values are increased relative to original Pettitt's test but there always remains significative ( $p$-values $<0.05$ ). The change point is confirmed in the same years by modified Pettitt test using TFPW ${ }_{\text {cur }}$ for both summer and autumn, while the date of change point has been brought upward by seven years (1993) for annual and backward by two years for spring (1991) compared with the original Pettitt's test.

Analysis of monthly temperatures series using original Pettitt test shows no trend in January, February, November and December, while a break point is observed in Mars $\left(+1.1^{\circ} \mathrm{C}\right)$, April $\left(+1.1^{\circ} \mathrm{C}\right)$, May $\left(+1,2^{\circ} \mathrm{C}\right)$, June $\left(+1.3^{\circ} \mathrm{C}\right)$, July $\left(+1,2^{\circ} \mathrm{C}\right)$, August $\left(+1,2^{\circ} \mathrm{C}\right)$, September $\left(+1.6^{\circ} \mathrm{C}\right)$ and October $\left(+1,2^{\circ} \mathrm{C}\right)$ respectively at the date $1986,1994,1991,1995,1993,1985,1982$ and1984. The P-value is generally less than 0.0001 except for March ( $p$-value= 0.02$)$ and September $(p-$ value=0.03). After using TFPW ${ }_{\mathrm{cu}}$ approach, the temperature series of Mars, April, May, June, July and August were tested again for shift using Pettitt's test. The results showed that $\mathrm{K}_{\mathrm{T}}$ values are decreased (table $\mathrm{xx}$ ) but $\mathrm{p}$-values remains significative ( $\mathrm{p}$-values=0.00) except for March where TFPW $\mathrm{Wu}_{\mathrm{cu}}$ approach has successfully eliminate the effect of autocorrelation (P-value=0.29). The date of change point detected by modified Pettitt test is affirmed in the same years only for May and August, while, it has been brought backward by three years for both April (1991) and June (1992) compared with the original Pettitt's test and been brough upward by for years in July (1997).

At Constantine station, the analysis of temperature time series using original Pettitt test shown that the annual temperature has change point in the year 1984 with an increase of $0.9^{\circ} \mathrm{C}$ ( $\mathrm{p}$-value $<0.0001$ ), while for seasonal time scales, spring, summer and autumn data series have reflected a shift respectively in the year $1993\left(+1.2^{\circ} \mathrm{C}\right), 1981\left(+1.5^{\circ} \mathrm{C}\right)$ and $1986\left(+1.1^{\circ} \mathrm{C}\right)$ and all having $\mathrm{p}$-values less than 0.0001 . Winter season has not detected any change point at $5 \%$ significance level. After using TFPWcu approach, it is found that all KT values are decreased (table xx), while the p-values are increased relative to original Pettitt's test but there always remains significative ( $p$-values $<0.05$ ). Also, the change point is affirmed in the same years by modified Pettitt test using TFPWcu.

Analysis of monthly temperatures series using original Pettitt test shows no trend in January, February, March, September, November and December, while a change point is observed in April $\left(+1.4^{\circ} \mathrm{C}\right)$, May $\left(+1,7^{\circ} \mathrm{C}\right)$, June $\left(+1,9^{\circ} \mathrm{C}\right)$, July $\left(+1,6^{\circ} \mathrm{C}\right)$, August $\left(+1,2^{\circ} \mathrm{C}\right)$, and October $\left(+2^{\circ} \mathrm{C}\right)$ respectively at the date $1997,1992,1992,1981,1985$ and 1985. After using TFPWcu approach, the temperature series of August and October were tested again for shift using Pettitt's test. The results showed that KT values are decreased (table $\mathrm{xx}$ ) but $\mathrm{p}$-values remains significative ( $\mathrm{p}$-values=0.00). The date of change point detected by modified Pettitt test is affirmed in the same years for the both months compared with the original Pettitt's test.

At Mascara station, the Analysis of temperature time series using original Pettitt test shown that the annual temperature has change point in the year 1996 with an increase of $0.9^{\circ} \mathrm{C}(\mathrm{p}$-value $=0.00)$, while for seasonal time scales, spring, summer and autumn data series have reflected a shift respectively in the year $1996\left(+1.3^{\circ} \mathrm{C}\right), 1997\left(+1.6^{\circ} \mathrm{C}\right)$ and $2000\left(+0.9^{\circ} \mathrm{C}\right)$ and having respectively a p-value of $0.001,0.002$ and 0.04 (table3). Winter season has not detected any change point at $5 \%$ significance level. After corrected and unbiased trend free prewhitening (TFPWcu), the annual, spring and summer temperature series were tested again for shift using Pettitt's test. The results showed that the $\mathrm{p}$-value is increased beyond the threshold of the significance of $5 \%$ for annual ( $\mathrm{P}$ value $=0.1$ ) and summer temperature ( $P$-value $=0.06)$. For the spring season, the change point date has been brought backward of four years $(1992)$ compared with the original Pettitt's test.

Analysis of monthly temperatures series using original Pettitt test shows no break in January, February, September, November and December, while a change point is observed in March $\left(+1.1^{\circ} \mathrm{C}\right)$, April $\left(+1.2^{\circ} \mathrm{C}\right)$, May $\left(+1,9^{\circ} \mathrm{C}\right)$, June $\left(+1,9^{\circ} \mathrm{C}\right)$, July $\left(+1,7^{\circ} \mathrm{C}\right)$, August $\left(+2,3^{\circ} \mathrm{C}\right)$, and October $\left(+1.9^{\circ} \mathrm{C}\right)$ respectively at the date $1988,1996,1993,1997,1997,1985$ and 1998 with the P-value less than 0.03 . The P-value calculated after using TFPWcu approach increased beyond the threshold of the significance of $5 \%$ for March (0.41), June (0.06) and August (0.32) series.

At Djelfa station, the Analysis of temperature time series using original Pettitt test shown that the annual temperature has change point in the year 1993 with an increase of $0.8^{\circ} \mathrm{C}(\mathrm{p}$-value $=0.00)$, while for seasonal time scales, spring, summer and autumn data series have reflected a shift respectively in the year $1985\left(+1.2^{\circ} \mathrm{C}\right), 1992\left(+1.2^{\circ} \mathrm{C}\right)$ and $1998\left(+0.9^{\circ} \mathrm{C}\right)$ and having respectively a P-value of $0.02,0.0004$ and 0.0004 (table 3$)$. Winter season has not detected 
any change point at $5 \%$ significance level. After using TFPWcu approach, the results show that the P-value calculated for annual and autumn auto-correlated temperature series is close to the critical value (0.05) that's why the detected change point has been eliminated. Analysis of monthly temperatures series using original Pettitt test shows no break in time series of January, February, May, June, September, November and December, while a change point is observed in March $\left(+1.2^{\circ} \mathrm{C}\right)$, April $\left(+1.6^{\circ} \mathrm{C}\right)$, July $\left(+1,3^{\circ} \mathrm{C}\right)$, August $\left(+1,4^{\circ} \mathrm{C}\right)$, and October $\left(+1.9^{\circ} \mathrm{C}\right)$ respectively at the date $1999,1982,1992,1985$ and 1998 . It is noted that at the monthly scale, all of the temperature series are not auto-correlated.

\subsection{Links between climate indices and temperature}

At the annual scale, the Pearson coefficient highlights a strong statistically significant positive correlation between the EA index and all of the annual temperature series (Table 4). The correlation coefficient varies between 0.4 and 0.73 and the stations in the East of the study area (name of the stations) are the ones with the highest correlations.

Statistically significant negative correlations not exceeding 0.36 are also observed between the WMO index and the annual temperatures for only the coastal stations (Algiers, Oran and Annaba). Indeed, Zeroual et al. (2016) highlighted the influence of this mode of circulation on the annual temperatures of northern Algeria during the period 1972-2013. Thus, the present result shows that the WMO index affected annual temperatures in the Mediterranean area long before 1972.

We also note of any significant correlations between the annual temperatures and the $\mathrm{NAO}, \mathrm{SOI}, \mathrm{AO}$ and $\mathrm{MO}$ indices, except in Algiers where a statistically significantly positive correlation is observed with $A O(R=0.3)$. However, this correlation is weak compared to the WMO and $E A$ indices.

For a seasonal time-scale, the analysis of the relationships between temperatures and the six climatic indices highlights highly significant correlations with the EA index for the different seasons of the year during the 1950-2016 study period. In winter, correlation coefficients of 0.46 to 0.57 are observed between the EA index and the temperatures of the six stations in northern Algeria, while there is no strong correlation with the other circulation modes. In the spring, EA also appears to be the dominant mode of circulation influencing the variability of temperatures during this season for all of the stations of the study area. Pearson's correlation coefficients vary between 0.33 and 0.62 (Table 4). In summer, the Pearson coefficient highlights strong correlations between the temperatures of the six stations and the EA index characterized by a correlation coefficient of 0.4 to 0.53 . Significant negative correlations stand out between the NAO index and the temperatures of Annaba, Constantine and Djelfa which show a correlation coefficient of $-0.27,-0.33,-0.34$ respectively (table 4 ). Significant negative correlations were also observed between the WMO index at the Algiers, Mascara and Djelfa stations, which recorded a correlation coefficient of approximately $-0.27,-0.44$ and -0.36 , respectively. However, the EA index remains the most dominant in summer for all stations. In autumn, significant positive correlations stand out between the EA index and all stations (except Mascara) $(0.30<r<0.41)$, while significant negative correlations appear between the WMO index and the temperatures of the six stations. of the study area with a correlation coefficient which varies from -0.30 to -0.61 (table 4). However, the Pearson coefficient shows that WMO is the dominant mode of circulation influencing temperatures in the study area in the autumn.

To better understand the variability of temperatures on a monthly scale, we have highlighted for each month the dominant circulation mode for the entire study area.

In general, in January, significant correlations are observed between temperatures and the EA, AO, NAO and MO indices (table 4). However, MO seems to be the most dominant mode of circulation in January for all stations (except Constantine) with a correlation coefficient which varies between -0.48 and -0.58 . We also note the strong influence of the EA index at the Annaba and Constantine stations located in the east of the country, which have a correlation coefficient of 0.47 and 0.41 respectively.

In February, very strong positive correlations were observed between the EA index and the temperatures of the entire study area. The correlation coefficient varies between 0.61 and 0.86 , while no significant correlation is observed with the other climatic indices.

The EA index also appears to be the dominant mode of circulation influencing the temperatures of the study area in March with a correlation coefficient that varies between 0.36 and 0.46 .

In April, temperatures were significantly correlated with the EA, MO and WMO climatic indices. At the coastal stations of Algiers, Annaba and Oran, EA is the dominant mode of circulation with a correlation coefficient which varies between 0.5 and 0.55 . In Constantine and Djelfa, the highest correlations are also observed with the EA index, while Mascara is strongly correlated with MO $(r=0.51)$ and WMO $(r=0.50)$.

In May, significant positive correlations were observed between the EA index and all stations. The correlation coefficient varies between 0.38 and 0.61 . To the east of the study area, we note the presence of significant negative correlations between the WMO index and the temperatures of Annaba and Constantine which show respectively an $r$ of -0.33 and -0.27 , however EA remains the mode of circulation the most dominant.

In June, low statistically significant negative correlations were observed between the WMO index and the temperatures in the coastal zone $(r=-0.28)$. In the highlands, the temperatures of Djelfa and Constantine show a low correlation with the EA index which is respectively of the order of 0.28 and 0.29 , while the mascara temperatures are strongly correlated with the WMO index $(r=-0.52)$.

In July and August, the highest correlation coefficients are observed with the EA index at the stations of Oran and Algiers, while the NAO and MO indices are the most correlated in Annaba. The stations located in the highlands show correlations with EA and NAO (table 4).

In September, statistically significant correlations were observed between temperatures and the EA and WMO indices at the coastal stations. While, on the highlands the EA index is the most dominant (table 4). 
In October, the strongest correlations were observed with the WMO index over the entire study area $(I 0.35|<r<| 0.54 \mid)$. In November, statistically significant correlations are distinguished between the temperatures of the coastal stations and the indices EA, NAO, WMO and MO, however EA and WMO are the dominant modes of circulation. On the highlands, the EA index is also the most correlated with Constantine, Djelfa and Mascara.

The variability of temperatures in December is influenced by different circulation modes mainly EA, MO, NAO. For the coastal stations, the correlation coefficient varies between 0.56 and 0.65 with the EA index and between -0.47 and -0.52 with the MO index, while the observed coefficients between temperatures and the NAO index vary between 0.4 and 0.44 (table 4). Regarding the highlands, in Constantine, the EA index is the most dominant mode of circulation $(r=0.53)$ followed by the NAO index $(r=-0.45)$. In mascara and Djelfa, it is rather MO which appears as the dominant mode of circulation (I0.54I $<r<10.57 \mathrm{I})$, followed by NAO $(10.41 \mid<r<10.47 \mathrm{I})$ then EA $(0.36<r<0.45)$.

Table 4: Pearson coefficient correlation between climate indices and temperature time series (at $5 \%$ significant level) 


\begin{tabular}{|c|c|c|c|c|c|c|c|c|c|c|c|c|c|c|c|c|c|}
\hline $\mathrm{Cl}$ & Jan. & Fev. & Mar. & Apr. & Mai & Juin & Jul & Aug & Sep. & Oct. & Nov. & Dec. & DJF & MAM & JJA & SON & an \\
\hline \multicolumn{18}{|l|}{ Algiers } \\
\hline EA & 0,37 & 0,8 & 0,36 & 0,55 & 0,5 & 0,25 & 0,28 & 0,31 & 0,34 & 0,23 & 0,38 & 0,56 & 0,48 & 0,43 & 0,46 & 0,38 & 0,58 \\
\hline AO & $-0,34$ & $-0,04$ & $-0,14$ & $-0,07$ & $-0,03$ & $-0,03$ & 0,15 & 0,22 & 0,19 & 0,02 & $-0,22$ & $-0,25$ & $-0,16$ & 0,08 & 0,28 & 0,15 & 0,3 \\
\hline NAO & $-0,38$ & 0,14 & $-0,12$ & 0,04 & 0,01 & $-0,16$ & $-0,2$ & $-0,23$ & 0,03 & $-0,21$ & $-0,29$ & $-0,4$ & $-0,21$ & 0,08 & $-0,2$ & $-0,21$ & $-0,03$ \\
\hline sol & 0,01 & 0,11 & 0 & 0,15 & $-0,08$ & $-0,15$ & 0,03 & 0,02 & $-0,02$ & $-0,07$ & $-0,12$ & $-0,09$ & $-0,02$ & 0,02 & $-0,05$ & $-0,13$ & $-0,09$ \\
\hline WMOI & $-0,25$ & 0,13 & $-0,02$ & $-0,29$ & $-0,24$ & $-0,28$ & $-0,21$ & $-0,07$ & $-0,28$ & $-0,5$ & $-0,33$ & $-0,31$ & $-0,02$ & $-0,16$ & $-0,27$ & $-0,43$ & $-0,35$ \\
\hline MO & $-0,53$ & $-0,17$ & $-0,08$ & $-0,43$ & $-0,1$ & $-0,25$ & $-0,22$ & $-0,2$ & 0,02 & $-0,17$ & $-0,35$ & $-0,52$ & $-0,08$ & $-0,15$ & 0,2 & $-0,2$ & $-0,04$ \\
\hline \multicolumn{18}{|l|}{ Oran } \\
\hline EA & 0,32 & 0,81 & 0,42 & 0,51 & 0,38 & 0,29 & 0,32 & 0,3 & 0,32 & 0,22 & 0,36 & 0,65 & 0,54 & 0,44 & 0,43 & 0,35 & 0,54 \\
\hline $\mathrm{AO}$ & $-0,45$ & 0,01 & $-0,12$ & $-0,15$ & 0 & 0,01 & 0,11 & 0,2 & 0,13 & 0,11 & $-0,25$ & $-0,32$ & $-0,26$ & $-0,05$ & 0,23 & 0,02 & 0,08 \\
\hline NAO & $-0,45$ & 0,22 & 0,01 & 0,13 & 0,16 & $-0,04$ & $-0,24$ & $-0,1$ & 0,1 & $-0,04$ & $-0,28$ & $-0,41$ & $-0,26$ & 0,18 & $-0,17$ & $-0,22$ & $-0,13$ \\
\hline sol & $-0,08$ & 0,16 & $-0,11$ & $-0,04$ & $-0,21$ & $-0,16$ & 0,15 & 0,07 & 0,1 & 0,08 & $-0,02$ & $-0,2$ & $-0,03$ & $-0,16$ & 0,03 & 0,03 & $-0,05$ \\
\hline WMOI & $-0,22$ & 0,09 & 0,07 & $-0,05$ & $-0,1$ & $-0,28$ & $-0,13$ & $-0,09$ & $-0,31$ & $-0,44$ & $-0,32$ & $-0,24$ & $-0,03$ & $-0,01$ & $-0,22$ & $-0,4$ & $-0,3$ \\
\hline MO & $-0,58$ & $-0,01$ & 0,19 & $-0,14$ & 0,13 & 0,02 & 0,05 & 0,06 & 0,17 & 0,14 & $-0,28$ & $-0,47$ & $-0,12$ & $-0,07$ & 0,15 & $-0,21$ & $-0,15$ \\
\hline \multicolumn{18}{|c|}{ Annaba } \\
\hline EA & 0,47 & 0,86 & 0,43 & 0,5 & 0,53 & 0,23 & 0,12 & 0,2 & 0,35 & 0,22 & 0,48 & 0,6 & 0,55 & 0,58 & 0,4 & 0,41 & 0,73 \\
\hline $\mathrm{AO}$ & $-0,31$ & $-0,03$ & $-0,16$ & $-0,04$ & $-0,01$ & $-0,13$ & 0,02 & 0,12 & 0,12 & $-0,13$ & $-0,11$ & $-0,34$ & $-0,18$ & 0,15 & 0,12 & 0,13 & 0,21 \\
\hline NAO & $-0,37$ & 0,18 & $-0,12$ & $-0,11$ & $-0,06$ & $-0,18$ & $-0,29$ & $-0,35$ & $-0,07$ & $-0,35$ & $-0,27$ & $-0,44$ & $-0,17$ & 0,05 & $-0,27$ & $-0,25$ & $-0,07$ \\
\hline sol & $-0,01$ & 0,08 & $-0,02$ & 0,07 & $-0,01$ & $-0,15$ & $-0,18$ & $-0,06$ & $-0,02$ & $-0,21$ & $-0,24$ & $-0,12$ & $-0,09$ & $-0,02$ & $-0,19$ & $-0,24$ & $-0,24$ \\
\hline WMOI & $-0,17$ & 0,16 & 0,08 & $-0,31$ & $-0,33$ & $-0,28$ & $-0,15$ & $-0,01$ & $-0,58$ & $-0,54$ & $-0,37$ & $-0,48$ & $-0,02$ & $-0,18$ & $-0,22$ & $-0,36$ & $-0,36$ \\
\hline MO & $-0,43$ & $-0,12$ & $-0,12$ & $-0,42$ & $-0,25$ & $-0,22$ & $-0,34$ & $-0,26$ & $-0,1$ & $-0,38$ & $-0,24$ & $-0,51$ & 0 & 0,06 & 0,11 & $-0,25$ & $-0,05$ \\
\hline \multicolumn{18}{|c|}{ Constantine } \\
\hline EA & 0,41 & 0,8 & 0,4 & 0,45 & 0,55 & 0,29 & 0,28 & 0,39 & 0,3 & 0,25 & 0,4 & 0,53 & 0,54 & 0,49 & 0,53 & 0,3 & 0,71 \\
\hline $\mathrm{AO}$ & $-0,38$ & $-0,06$ & $-0,15$ & 0,02 & 0 & $-0,18$ & $-0,18$ & 0,02 & 0,13 & $-0,17$ & $-0,17$ & $-0,37$ & $-0,24$ & 0,08 & 0,01 & 0,08 & 0,18 \\
\hline NAO & $-0,39$ & 0,19 & $-0,08$ & $-0,23$ & $-0,01$ & $-0,25$ & $-0,4$ & $-0,32$ & $-0,03$ & $-0,35$ & $-0,23$ & $-0,45$ & $-0,21$ & $-0,1$ & $-0,33$ & $-0,19$ & $-0,07$ \\
\hline sol & $-0,04$ & 0,09 & $-0,02$ & 0,18 & $-0,08$ & $-0,18$ & $-0,05$ & $-0,05$ & $-0,01$ & $-0,13$ & $-0,16$ & $-0,12$ & $-0,09$ & 0,01 & $-0,16$ & $-0,13$ & $-0,15$ \\
\hline WMOI & $-0,22$ & 0,12 & $-0,04$ & $-0,43$ & $-0,27$ & $-0,2$ & $-0,07$ & 0,07 & $-0,1$ & $-0,39$ & $-0,22$ & $-0,28$ & 0,01 & $-0,22$ & $-0,17$ & $-0,3$ & $-0,25$ \\
\hline MO & 0,04 & 0,04 & 0,14 & 0,07 & $-0,04$ & 0,17 & 0,02 & 0,03 & $-0,23$ & $-0,29$ & 0 & 0,12 & $-0,11$ & $-0,02$ & 0,09 & $-0,32$ & $-0,07$ \\
\hline \multicolumn{18}{|c|}{ Mascara } \\
\hline EA & 0,42 & 0,7 & 0,4 & 0,23 & 0,61 & 0,19 & 0,38 & 0,42 & 0,22 & 0,19 & 0,39 & 0,45 & 0,57 & 0,33 & 0,49 & 0,2 & 0,47 \\
\hline $\mathrm{AO}$ & $-0,27$ & $-0,11$ & $-0,03$ & 0,31 & 0,17 & $-0,19$ & $-0,07$ & 0,02 & 0,08 & $-0,09$ & $-0,03$ & $-0,43$ & $-0,09$ & 0,13 & 0,23 & $-0,02$ & 0,31 \\
\hline NAO & $-0,39$ & 0,19 & $-0,08$ & $-0,23$ & $-0,01$ & $-0,25$ & $-0,4$ & $-0,32$ & $-0,03$ & $-0,35$ & $-0,23$ & $-0,47$ & $-0,23$ & 0,12 & $-0,07$ & $-0,46$ & $-0,20$ \\
\hline sol & 0,05 & 0,15 & 0,14 & 0,15 & $-0,26$ & $-0,06$ & 0,02 & 0,06 & $-0,13$ & 0,2 & 0,07 & $-0,04$ & 0,14 & 0,12 & $-0,05$ & 0,13 & 0,16 \\
\hline WMOI & $-0,26$ & 0,15 & $-0,18$ & $-0,5$ & $-0,26$ & $-0,52$ & $-0,24$ & $-0,25$ & $-0,21$ & $-0,42$ & $-0,14$ & $-0,24$ & $-0,16$ & $-0,3$ & $-0,44$ & $-0,61$ & $-0,18$ \\
\hline MO & $-0,53$ & $-0,09$ & $-0,07$ & $-0,51$ & $-0,21$ & $-0,32$ & $-0,32$ & $-0,2$ & $-0,08$ & $-0,41$ & $-0,24$ & $-0,54$ & $-0,36$ & $-0,05$ & 0,15 & $-0,17$ & 0,19 \\
\hline \multicolumn{18}{|l|}{ Djelfa } \\
\hline EA & 0,28 & 0,61 & 0,46 & 0,59 & 0,59 & 0,28 & 0,45 & 0,52 & 0,54 & 0,24 & 0,49 & 0,36 & 0,47 & 0,62 & 0,47 & 0,32 & 0,40 \\
\hline $\mathrm{AO}$ & $-0,23$ & $-0,3$ & $-0,28$ & 0,08 & $-0,02$ & 0,01 & $-0,08$ & $-0,08$ & 0,28 & $-0,15$ & $-0,14$ & $-0,28$ & $-0,33$ & $-0,01$ & $-0,02$ & 0,09 & 0,04 \\
\hline NAO & $-0,25$ & $-0,11$ & 0,06 & 0,03 & 0,23 & $-0,03$ & $-0,32$ & $-0,41$ & 0,12 & $-0,28$ & $-0,01$ & $-0,41$ & $-0,23$ & 0,03 & $-0,34$ & $-0,24$ & $-0,27$ \\
\hline sol & 0,06 & 0,13 & $-0,19$ & 0,22 & 0,07 & $-0,25$ & $-0,04$ & $-0,12$ & 0,07 & $-0,11$ & $-0,15$ & $-0,2$ & $-0,07$ & 0,05 & $-0,2$ & $-0,08$ & 0,05 \\
\hline WMOI & $-0,09$ & 0,01 & 0,08 & $-0,46$ & $-0,15$ & $-0,22$ & $-0,03$ & $-0,1$ & $-0,16$ & $-0,45$ & $-0,26$ & $-0,15$ & 0,15 & $-0,08$ & $-0,36$ & $-0,4$ & $-0,27$ \\
\hline MO & $-0,48$ & $-0,11$ & 0,16 & $-0,42$ & 0,01 & $-0,06$ & $-0,12$ & $-0,24$ & 0,09 & $-0,23$ & $-0,39$ & $-0,57$ & $-0,24$ & 0,03 & 0,07 & $-0,39$ & 0,06 \\
\hline
\end{tabular}


Following these outcomes, it seems that the EA index affects the variability of temperatures during the different months of the year, however it is during the winter (December and February) and spring (March, April and May months) that it has the greatest influence. According to NOAA (2018), the positive phase

EA is associated with above-average surface temperatures in Europe (Mediterranean) during all the months, which explains the rise in temperatures observed in spring and summer North of Algeria.

In December and January, the MO index has a great influence on the temperatures of the study area. Dünkeloh and Jacobeit (2003) considers that MO is strongly linked in winter to the Arctic (AO) and North Atlantic (NAO) oscillations. In fact, the results clearly showed the influence of these three modes of circulation on the temperatures of the study area in December and January. However, MO is the most dominant mode. These results corroborate with the work of Sušelj and Bergant (2006) who found significant correlations with NAO and MO but which are stronger with MO at the scale of the Mediterranean basin. In Lebanon, Ramadan et al (2012) also found significant negative correlations with MO in winter, as did Nastos et al. (2011) in Greece. NAO also influences temperatures during the winter months (December and January) over the entire study area and during the summer months (July and August) on the high plateaus, which coincides with the study of Ramadan et al. (2012) who found negative correlations with NAO in Lebanon in summer, autumn and winter. Negative correlations between temperatures and NAO have also been confirmed for the entire western Mediterranean region by Hurrel (1995) and Trigo et al. (2004). Strong positive phases of NAO tend to be associated with above normal temperatures in the eastern United States and northern Europe and below normal temperatures in Greenland and often in southern Europe and the Middle East (NOAA 2018), which explains the negative correlations between this index and the monthly temperatures in our study area. It is probably for this reason that the temperatures of Northern Algeria do not show a significant trend in winter (table 2 and 3). The results obtained show that AO influences the temperatures of northern Algeria in December and January just like NAO but in a moderate way. According to Marshall et al. (2001) NAO can be considered as the regional expression of AO. Wang et al. (2005) have shown that $\mathrm{AO}$ influences the variability of winter temperatures in the European, Asian and African continents, while the NAO is more regional and mainly influences North-West Africa. Also, Rust et al. (2015) found negative correlations with NAO and AO across North Africa, NAO being the most dominant mode in January. This confirms the results set out above.

The AO index experienced a downward trend during the period 1950-1970, then an upward trend between 1970 and 1990 and a downward trend during the period 1990-2010, which indicates its multi -decadal variability (Tanaka and Tamura 2016). The negative phase of AO observed between $1990-2010$-while temperatures on a global scale have continued to increase- shows that this index does not participate in global warming in recent years (Tanaka and Tamura 2016). This negative phase probably influenced the temperatures in our study area, which did not record significant warming in winter (table 2 and 3 ).

The WMO index appears to be the dominant mode of circulation in the autumn, its negative phase observed since 1990

(http://www.ub.edu/gc/en/2016/06/08/wemo/) seems to explain the significant increase in temperatures recorded particularly in October for all the stations in the study area (table 2 and 3). Indeed, Martin et al. (2012) found that high temperatures are associated with negative WMO values while low temperatures are correlated with positive WMO values in the North-West Mediterranean. Rios-Cornejo et al. (2015) also found negative correlations with the WMO in the months of April, May, June, September and October in the North and West regions of Spain, with a correlation coefficient which varies between - 0.36 and -0.41 .

ENSO has always been considered responsible for global warming. Some studies have highlighted the influence of ENSO on average temperatures (Hafez and Robaa 2008; Latif and Keenlyside 2009). However, the results obtained show no significant correlation between the temperatures of northern Algeria and the SOI index for all the stations, which coincides with the work carried out by Zeroual et al. (2016) in Algeria, Ramadan et al. (2012) in Lebanon and Rust et al. (2015) on the Euro-Mediterranean region.

\section{Discussion}

The analysis of temperature trends at six stations in northern Algeria over the period 1950-2016 was approached using six different versions of the Mann Kendall test. The comparison between the versions of the MMK based on different approaches compared to the traditional Mann-kendall test showed overall that the MMK-pw and MMK-TFPW-cu tests are the most effective in eliminating the effect of autocorrelation. These two tests s are able to reduce the Zstatistic by more than $50 \%$ until the total elimination of the trend for some temperature series, while other approaches generally do not exceed $30 \%$, contrary to the MMK-TFPW test which often shows an increase in the Z-statistic,

These percentages can be explained by not considering the increase in variance (Serinaldi and Kylbi 2016). Concerning the detection of long-term persistence, we find that the LTP test greatly reduces the number of temperature series with a significant trend by the original MK test as well as the other tests. The $\mathrm{H}$ coefficient, which varies on average between 0.3 and 0.7 , was able to detect the presence of long-term persistence for some temperature series, however its elimination makes the trend insignificant for all temperature series.

Rupture detection within temperature series was addressed using the Pettitt test as well as the Modified Pettitt test based on the TFPW-cu approach for autocorrelated series. After removing the autocorrelation using the TFPW-cu approach, it was found that values of $\mathrm{K}_{\mathrm{T}}$ statistic are decreased, while the $\mathrm{p}$ values are increased compared with the original Pettitt's test. In addition, the date of change point has been brought backward/ forward by one year (or more) in comparison to original Pettitt's test

For the Algiers, Oran, Annaba and Constantine stations, the break in the temperature series observed at the different time scale (annual, seasonal and monthly) remains significant after the application of the TFPW-cu approach and the break date is often the same or shifted from one year to 3 years. At Djelfa and Mascara stations, the modified Pettitt test completely eliminated the change point for all auto-correlated temperature series regardless of the time scale. This is probably due to the fact that the p-value calculated before applying TFPW-cu is close to the significance threshold 0.05 . 
On the annual scale, the significant positive trends observed for all stations show an increase of 0.1 to $0.4^{\circ} \mathrm{C} /$ decade which is more pronounced in the semiarid regions represented by Djelfa and Mascara stations. Such a temperature increase has already been noted by Driouch et al. (2013) in Morocco and Tunisia, by Zeroual et al. (2016) in Algeria and other countries around the Mediterranean (Chaouche et al. 2010 Ramos et al. 2012; Barteloni et al. 2012; Mamara et al. 2016; Feidas et al. 2016 Dogan et al. 2015). The elimination of the persistence shown by the coefficient $H$, for the different stations, makes the trends insignificant.

The modified test of Pettitt shows an increase of 0.8 to $0.9^{\circ} \mathrm{C}$ for the annual temperatures observed from the 1980 s except Djelfa and Mascara stations. In general, the annual temperature trend seems to be associated with an increase of the temperatures of autumn, spring and summer while no significant change is observed in winter. Similarities stand out in the Mediterranean region with the obtained results. Indeed, Toreti et al. (2010) noted positive trends in Italy between 1970 and 1980 in autumn, spring and summer, while winter shows no significant trend. An increase in temperatures in spring and summer has also been observed in Morocco (Filahi et al. 2016), in Italy (Bartolini et al. 2012; Caloiero et al. 2017) in Greece (Feidas et al. 2016) and in Spain (Del Rio et al. 2011; Ramos et al. 2012). While, considerable warming during all seasons has been noted in Lebanon (Ramadan et al. 2013) as well as in Tunisia (Dorte 2013). The LTP test indicates the presence of long-term persistence in spring and autumn at the level of Algiers and Annaba stations, in spring and autumn for Oran station and for all seasons at the Constantine station, however its elimination makes the trends not significant.

Statistical tests have shown that the temperature variability observed on a monthly scale is generally manifested during the months from April to October marked by an increase of 0.1 to $0.9^{\circ} \mathrm{C} /$ decade. The month of October is characterized by a strong temperature increase of about $2^{\circ} \mathrm{C}$ observed since the mid1980 s for the coast and since the end of the 1990s for the high plateaux. In Greece, Mamara et al. (2016) found an increase in temperatures between May and October, while Del Rio et al. (2011) noted an increase in temperatures in Spain during the months of March, June and August. The number of monthly temperature series indicating the presence of long-term persistence is greater at the Oran and Mascara stations located in the west of the country, however the elimination of the persistence by the LTP test shows the absence of the significant trend for all of these series.

The analysis of the relationships between the temperatures of northern Algeria and six climatic indices has shown that EA is the dominant circulation mode influencing the annual variability of temperatures. The positive phase of this index is associated with the increase in temperatures observed over the study period (1950-2016). These results are in line with studies conducted by Ramadan et al. (2012), Rios-Cornejo et al. (2016), Rust et al. (2015), Toreti et al. (2010) which found strong correlations between annual temperatures and EA.

The winter temperature averages are strongly correlated with the EA index for all stations, while no significant trend was observed during the study period. It is important to note that the temperature variability of December and January are strongly influenced, in order, by the MO, NAO and AO index. MO is strongly related to NAO and AO oscillations in winter (Dünkeloh and Jacobeit 2003). The positive phase of NAO is linked to the below-average winter temperatures in the Mediterranean region, which may explain the absence of positive temperature trends in northern Algeria during this season. Türkeş and Erlat (2009) have also shown that the positive phase of NAO is associated with lower winter temperatures in Turkey, as did Rust et al. (2015) who found negative correlations with NAO for all of North Africa in January.

In spring and summer, the temperature increase is mainly related to the positive phase of EA at the different scales (annual and monthly). In autumn, it is clear that the temperature increase is associated with the negative phase of the WMO and particularly during the month of October which is characterized by a significant temperature increase where strong correlations are observed with this index for all stations. EA is the second mode also influencing temperatures in autumn.

\section{Conclusion}

The objective of this work was to analyse the variability of mean temperatures in northern Algeria and its relationship with the general atmospheric circulation through six rainfall stations during the period 1950-2016. Recent studies have shown that it is necessary to remove the effect of autocorrelation when analysing trends or breaks in a series of autocorrelated hydro-climatic data using different approaches to identify trends and find their significance in an acceptable manner.

To do this, a comparison between several statistical tests, using different approaches, was carried out on all temperature series and at different time scales. It appears that all these approaches do not systematically eliminate the trend observed in an autocorrelated series. However, for some temperature series, the PW and TFPW-cu -preblanking methods were found to be the most effective in eliminating the autocorrelation effect. However, the elimination of the persistence effect by the LTP test rendered the trends insignificant. Our objective is not to highlight the best suitable test for analysing trends or breaks, but to use more than one approach to identify trends and find their significance in an acceptable way for consideration in planning action and decision making and for coping with global warming.

The coastal region of Algeria is marked by a warming of 0.8 to $0.9^{\circ} \mathrm{C}$ observed since the $1980 \mathrm{~s}$. This warming most often exceeds $1^{\circ} \mathrm{C}$ on a seasonal scale, particularly in summer, while no significant trend is observed in winter. On the highlands, the warming is most noticeable on a monthly scale between April and October, exceeding $1^{\circ} \mathrm{C}$ and reaching $2^{\circ} \mathrm{C}$ in October. These findings show that global warming has also affected the Algerian interior as far as more than $100 \mathrm{~km}$ from the Mediterranean Sea.

The interannual variability of temperatures in northern Algeria is influenced by the EA index. This circulation pattern seems to affect every month of the year. Its positive phase is responsible for the temperature increase. On the other hand, the absence of warming during the winter months seems to be associated with the activity of the NAO and the MO, known for their influence, particularly in January, by a drop in temperatures in the Mediterranean region. The WMO is very active in autumn and seems to explain the observed warming, especially in October. 
Finally, this work has shown that the observed large-scale warming affects the different regions of Algeria. The impact of this warming has already been felt in the past through a long period of drought characterized by a significant rainfall deficit which has strongly affected the availability of water resources for drinking water supply and agriculture in Algeria. However, taking into account the climate projections indicated by the IPCC in 2014 , this warming is likely to increase further and could reach $4^{\circ} \mathrm{C}$ by the end of the century, if no mitigation measures are taken, which will worsen the current situation. For this reason, adaptation measures are needed by carrying out socio-economic and environmental impact studies.

\section{Declarations}

Funding (Not applicable)

Conflicts of interest/Competing interests (Not applicable)

Availability of data and material (Not applicable)

Code availability (Not applicable)

Ethics approval (Not applicable)

Consent to participate (Not applicable)

Consent for publication (Not applicable)

\section{Author's contribution}

All authors contributed to the study conception and design. Data collection and analysis were performed by [TAïB S.] and [Zeroual Ayoub]. The first draft of the manuscript was written by TAÏBI S. and all authors discussed the results and contributed to the final manuscript.

\section{Acknowledgments}

The authors would like to thank The National Office of meteorology (office National de Météorologie) for providing data series.

\section{References}

1. Barnston A, Livezey RE (1987) Classification, seasonality and persistence of low-frequency circulation patterns. Mon Weather Rev $115: 1083-1126$

2. Bartolini G, di Stefano V, Maracchi G, Orlandini S (2012) Mediterranean warming is especially due to summer season Evidences from Tuscany (central Italy). Theor Appl Climatol 107:279-295. https://doi:10.1007/s00704-011-0481-1

3. Bekkoussa B, Meddi M, Jourde H (2008) Forçage climatique et anthropique sur la ressource en eau souterraine d'une région semi-aride: Cas de la plaine de Ghriss (Nord-Ouest algérien). Sécheresse 18:173-184

4. Bensaoula F, Collignon B, Adjim M (2019) Assessment of Groundwater Resources in the Jurassic Horst (Western Algeria). In: The Handbook of Environmental Chemistry. Springer, Berlin, pp 1-42. https://doi.org/10.1007/698_2019_406

5. Boko M, Niang I, Nyong A, Vogel C, Githeko A, Medany M, Osman-Elasha B, Tabo R, Yanda P (2007) Africa. Climate Change 2007: Impacts, Adaptation and Vulnerability. In: Parry M, Parry ML, Canziani O, Palutikof J, Van der Linden P, Hanson C (eds) Contribution of Working Group II to the Fourth Assessment Report of the Intergovernmental Panel on Climate Change, Cambridge University Press, Cambridge UK, pp 433-467

6. Bouabdelli S, Meddi M, Zeroual A, Alkama R (2020) Hydrological drought risk recurrence under climate change in the karst area of Northwestern Algeria. Journal of Water Climate Change https://doi: https://https://doi.org/10.2166/wcc.2020.207

7. Caloiero T, Coscarelli R, Ferrari E, Sirangelo B (2017) Trend analysis of monthly mean values and extreme indices of daily temperature in a region of southern Italy. International journal of climatology 37:284-297. https://doi.org/10.1002/joc.5003

8. Chaouche K, Neppel L, Dieulin C, Pujol N, Ladouche B, Martin E, Salas D, Caballero Y (2010) Analyses of precipitation, temperature and evapotranspiration in a French Mediterranean region in the context of climate change. CR Geosci 342:234-243.

https://doi.org/10.1016/j.crte.2010.02.001

9. Chebil A, Mtimet N, Tizaoui H (2011) Impact du changement climatique sur la productivité des cultures céréalières dans la région de Béja (Tunisie). AfJARE 6:144-154

10. Conte M, Giuffrida A, Tedesco S (1989) The Mediterranean Oscillation. Impact on precipitation and hydrology. in Conference on Climate Water, Publications of the Academy of Finland, Helsinki, pp121-137

11. Cunderlik JM, Burn DH (2004) Linkages between regional trends in monthly maximum flows and selected climatic variables. ASCE J Hydrol Eng 9:246256

12. Dai A (2011) Drought under global warming: a review. Wiley Interdiscip Rev Clim Chang: 2:45-65. https://doi.org/10.1002/wcc.81

13. Data P, Das S (2019) Analysis of long-term precipitation changes in West Bengal, India: An approach to detect monotonic trends influenced by autocorrelations. Dyn Atmos Oceans 88:101-118. https://doi.org/10.1016/j.dynatmoce.2019.101118

Page 20/24 
14. Dogan M, Ulke A, Cigizoglu HK (2015) Trend direction changes of Turkish temperature series in the first half of 1990s. Theor Appl Climatol 121:23-39. https://doi:10.1007/s00704-014-1209-9

15. Dorte V (2013) Tunisia in a changing climate: assessement and actions for increased resilience and development. World Bank, Washington, DC

16. Driouech F, Rached SB, Hairech TE (2013) Climate Variability and Change in North African Countries. In: Sivakumar M, Lal R, Selvaraju R, Hamdan I (eds) Climate Change and Food Security in West Asia and North Africa. Springer, Dordrech, pp 161-172

17. Dünkeloh A, Jacobeit J (2003) Circulation dynamics of Mediterranean precipitation variability 1948-98. Int J Climatol 23:1843-1866. https://doi.org/10.1002/joc. 973

18. Durand F (2007) Le réchauffement climatique en débats: incertitudes, acquis et enjeux. Ellipses

19. Eichner JF, Koscielny-Bunde E, Bunde A, Havlin S, Schellnhuber HJ (2003) Power-law persistence and trends in the atmosphere: A detailed study of long temperature records. Phys Rev E. https://doi.org/10.1103/PhysRevE.68.046133

20. Fathian F, Dehghan Z, Bazrkar MH, Eslamian S (2016) Trends in hydrological and climatic variables affected by four variations of the Mann-Kendall approach in Urmia Lake basin, Iran. Hydrol Sci J 61:892-904. https://doi.org/10.1080/02626667.2014.932911

21. Feidas H (2016) Trend analysis of air temperature time series in Greece and their relationship with circulation using surface and satellite data: recent trends and an update to 2013. Theor Appl Climatol 129:1383-1406. https://doi:10.1007/s00704-016-1854-2

22. Giorgi F (2006) Climate change hot-spots. Geophys Res Lett. https://doi:10.1029/2006GL025734

23. Hafez YY, Robaa SM (2008) The Relationship between the Mean Surface Air Temperature in Egypt and NAO Index and ENSO. The Open Atmospheric Science Journal 2:8-17

24. Hamed KH (2008) Trend detection in hydrologic data: the Mann-Kendall trend test under the scaling hypothesis. J Hydrol 349:350-363. https://doi:10.1016/j.jhydrol.2007.11.009

25. Hamed KH, Rao AR (1998) A modified Mann-Kendall trend test for autocorrelated data. J Hydrol 204:182-196

26. Hurrell JW (1995) Decadal Trends in the North Atlantic Oscillation: regional temperatures and precipitation. Science 269:676-679

27. IPCC (2007) Climate Change 2007: Synthesis Report. Contribution of Working Groups I, II and III to the Fourth Assessment Report of the Intergovernmental Panel on Climate Change, Geneva, Switzerland

28. IPCC (2014) Climate Change 2014: Synthesis Report. Contribution of Working Groups I, II and III to the Fifth Assessment Report of the Intergovernmental Panel on Climate Change, Geneva, Switzerland

29. Kendall MG (1975) Rank Correlation Measures. Charles Griffın, London

30. Koutsoyiannis D (2003) Climate change, the Hurst phenomenon, and hydrological statistics. Hydrol Sci J 48:3-24. https://doi.org/10.1623/hysj.48.1.3.43481

31. Koutsoyiannis D, Montanari A (2007) Statistical analysis of hydroclimatic time series: uncertainty and insights. Water Res Res 43:W05-W429. https://doi.org/10.1029/2006WR005592

32. Kulkarni A, von Storch H (1995) Monte Carlo experiments on the effect of serial correlation on the Mann-Kendall test of trend. Meteorol Z 4:82-85

33. Kumar S, Merwade V, Kam J, Thurner K (2009) Streamflow trends in Indiana: effects of long-term persistence, precipitation and subsurface drains. J Hydrol 374:171-183. https://doi:10.1016/j.jhydrol.2009.06.012

34. Latif M, Keenlyside NS (2009) El Nino/Southern Oscillation response to global warming. PNAS 106: 20578 - 20583. 10.1073/pnas.0710860105

35. Lee JH, Julien PY, Maloney ED (2019) The variability of South Korean temperature associated with climate indicators. Theor Appl Climatol 138:469-489. https://doi.org/10.1007/s00704-019-02842-8

36. Martín-Vide J et Lopez-Bustins JA (2006) The Western Mediterranean Oscillation and rainfall in the Iberian Peninsula. Int J Climatol 26:1455-1475

37. Mamara A, Argiriou A, Anadranistakis M (2016) Recent trend analysis of mean air temperature in Greece based on homogenized data. Theor Appl Climatol 126:543-573. https://doi.org/10.1007/s00704-015-1592-x

38. Mann HB (1945) Nonparametric tests against trend. Econometrica 13:245-259

39. Marshall J, Kushnir Y, Battisti D, Chang P, Dickson R, Hurrell J, Cartney M, Saravanan R, Czaja A, Visbeck M (2001) North atlantic climate variability: phenomena, impacts and mechanisms. Int J Climatol 21:1863-1898. https://doi.org/10.1002/joc.693

40. Martín P, Sabatés A, Lloret J, Martín-Vide J (2012) Climate modulation of fish populations: the role of the Western Mediterranean Oscillation (WeMO) in sardine (Sardina pilchardus) and anchovy (Engraulis encrasicolus) production in the north-western Mediterranean. Clim Change 110:925-939. https://doi.org/10.1007/s10584-011-0091-z

41. Meddi H, Meddi M (2009) Variabilité des précipitations annuelles du Nord-Ouest de l'Algérie. Sécheresse 20:173-184

42. Medjerab A, Henia L (2005) Régionalisation des pluies annuelles dans l'Algérie Nord-Occidentale. Revue géographique de l'Est, Climat, sécheresse et canicule 45:1-15

43. Nastos PT, Philandras CM, Founda D, Zerefos CS (2011) Air temperature trends related to changes in atmospheric circulation in the wider area of Greece. Int J Remote Sens 32:737-750. 10.1080/01431161.2010.517796

44. NOAA (2018) https://www.ncdc.noaa.gov/cdo-web/

45. Pettitt AN (1979) A non-parametric approach to the change-point problem. Appl Stat 28:126-135. http://doi:10.2307/2346729

46. Piyoosh AK, Ghosh SK (2017) Effect of autocorrelation on temporal trends in rainfall in a valley region at the foothills of Indian Himalayas. Stoch Environ Res Risk Assess 31::2075-2096. https://doi.org/10.1007/s00477-016-1347-y

Page $21 / 24$ 
47. Plewa K, Perz A, Wrzesiński D (2019) Links between Teleconnection Patterns and Water Level Regime of Selected Polish Lakes. Water. https://doi.org/10.3390/w11071330

48. Price RA (2017) Climate change and stability in North Africa. K4D Helpdesk Report 242. Institute of Development Studies, Brighton

49. Radhouane $L$ (2013) Climate change impacts on North African countries and on some Tunisian economic sectors. JAEID 107:101-113

50. Ramadan HH, Ramamurthy AS, Beighley RE (2012) Inter-Annual Temperature and Precipitation Variations over the Litani Basin in Response to Atmospheric Circulation Patterns. Theoret Appl Climatol 108:563-577. https://doi.org/10.1007/s00704-011-0554-1

51. Ramadan HH, Beighley RE, Ramamurthy AS (2013) Temperature and Precipitation Trends in Lebanon's Largest River: The Litani Basin. J Water Resour Plan Manag. https://doi.org/10.1061/(ASCE)WR.1943-5452.0000238

52. Ramos MC, Balasch JC, Martínez-Casasnovas JA (2012) Seasonal temperature and precipitation variability during the last 60 years in a Mediterranean climate area of Northeastern Spain: a multivariate analysis. Theor Appl Climatol 110:35-53. https://doi:10.1007/s00704-012-0608-z

53. Ríos-Cornejo D, Penas Á, Álvarez-Esteban R, Del Río S (2015) Links between teleconnection patterns and mean temperature in Spain. Theor Appl Climatol 122:1-18. https://doi.org/10.1007/s00704-014-1256-2

54. Rust HW, Richling A, Bissolli P, Ulbrich U (2015) Linking teleconnection patterns to European temperature: a multiple linear regression model. Meteorol Z 24:411-423

55. Sen PK (1968) Estimates of the regression coefficient based on Kendall's tau. J Am Stat Assoc 63:1379-1389

56. Serinaldi F, Kilsby CG (2016) The importance of prewhitening in change point analysis under persistence. Stoch Env Res Risk Assess 30:763-777

57. Sowers J, Vengosh A, Weinthal E (2011) Climate change, water resources, and the politics of adaptation in the Middle East and North Africa. Clim Change 104:599-627. https://doi.org/10.1007/s10584-010-9835-4

58. von Storch VH (1995) Misuses of statistical analysis in climate research, In: Analysis of Climate Variability: Applications of Statistical Techniques. In: von Storch V, Navarra A (eds). Springer- Verlag, Berlin, pp 11-26

59. Sušelj K, Bergant K (2006) Mediterranean Oscillation Index. Geophysical Research Abstracts 8:1-2

60. Taibi S, Meddi M, Mahé G, et Assani A (2017) Relationships between atmospheric circulation indices and rainfall in Northern Algeria and comparison of observed and RCM-generated rainfall. Theoret Appl Climatol 127:241-257. https://doi.org/10.1007/s00704-015-1626-4

61. Tanaka HL, Tamura M (2016) Relationship between the Arctic oscillation and surface air temperature in multi-decadal time-scale. Polar Sci 10:199-209. https://doi.org/10.1016/j.polar.2016.03.002

62. Thompson DW, Wallace JM, Hegerl GC (2000) Annular modes in the extratropical circulation. Part II: Trends. J Clim 13:1018-1036

63. Thompson DWJ, Wallace JM (1998) The Arctic Oscillation signature in wintertime geopotential height and temperature fields. Geophys Res Lett 25:1297-1300

64. Toreti A, Desiato F, Fioravanti G, Perconti W (2010) Seasonal temperatures over Italy and their relationship with low-frequency atmospheric circulation patterns. Clim Change 99:211-227. HTTPS://DOI 10.1007/s10584-009-9640-0

65. Trigo RM, Pozo-Vazquez D, Osborn TJ, Castro-Diez Y, Gamiz-Fortis S, Esteban-Parra MJ (2004) North Atlantic oscillation influence on precipitation, river flow and water resources in the Iberian peninsula. Int J Climatol 24:925-944

66. Türkeş M, Erlat E (2009) Winter mean temperature variability in Turkey associated with the North Atlantic Oscillation. Meteorol Atmos Phys 105:211225. https://doi.org/10.1007/s00703-009-0046-3

67. Vancutsem C, Ceccato P, Dink T, Connor SJ (2010) Evaluation of MODIS land surface temperature data to estimate air temperature in different ecosystems over Africa. Remote Sens Environ 114:449-465

68. Wallace JM, Gutzler DS (1981) Teleconnections in geopotential height field during the Northern Hemisphere winter. Mon Weather Rev 109:784-812

69. Wang D, Wang C, Yang X, Lu J (2005) Winter Northern Hemisphere surface air temperature variability associated with the Arctic Oscillation and North Atlantic Oscillation. Geophysical Research Letters. https://doi:10.1029/2005GL022952

70. Yu B, Lin H, Soulard N (2019) A comparison of north american surface temperature and temperature extreme anomalies in association with various atmospheric teleconnection patterns. Atmosphere. https://doi.org/10.3390/atmos10040172

71. Yue S, Wang CY (2004) The Mann-Kendall test modified by effective sample size to detect trend in serially correlated hydrological series. Water Resour Manag 18:201-218

72. Yue S, Pilon P, Phinney B, Cavadias G (2002) The influence of autocorrelation on the ability to detect trend in hydrological series. Hydrol Process 16:1807-1829

73. Zamani R, Mirabbasi R, Abdollahi S, Jhajharia D (2017) Streamflow trend analysis by considering autocorrelation structure, long-term persistence, and Hurst coefficient in a semi-arid region of Iran. Theoret Appl Climatol 129:33-45. https://doi.org/10.1007/s00704-016-1747-4

74. Zeroual A, Assani AA, Medd M, Alkama R (2019) Assessment of climate change in Algeria from 1951 to 2098 using the Köppen-Geiger climate classification scheme. Clim Dyn 52:227-243. https://doi.org/10.1007/s00382-018-4128-0

75. Zeroual A, Assani AA, Meddi M (2016) Combined analysis of temperature and rainfall variability as they relate to climate indices in Northern Algeria over the 1972-2013 period. Hydrology research. https://doi.org/10.2166/nh.2016.244

76. Zhang R (2017) Atmospheric science: warming boosts air pollution. Nat Clim Chang 7:238-239. https://doi.org/10.1038/nclimate3257

\section{Figures}






Figure 1

Location of study area and meteorological stations Note: The designations employed and the presentation of the material on this map do not imply the expression of any opinion whatsoever on the part of Research Square concerning the legal status of any country, territory, city or area or of its authorities, or concerning the delimitation of its frontiers or boundaries. This map has been provided by the authors.
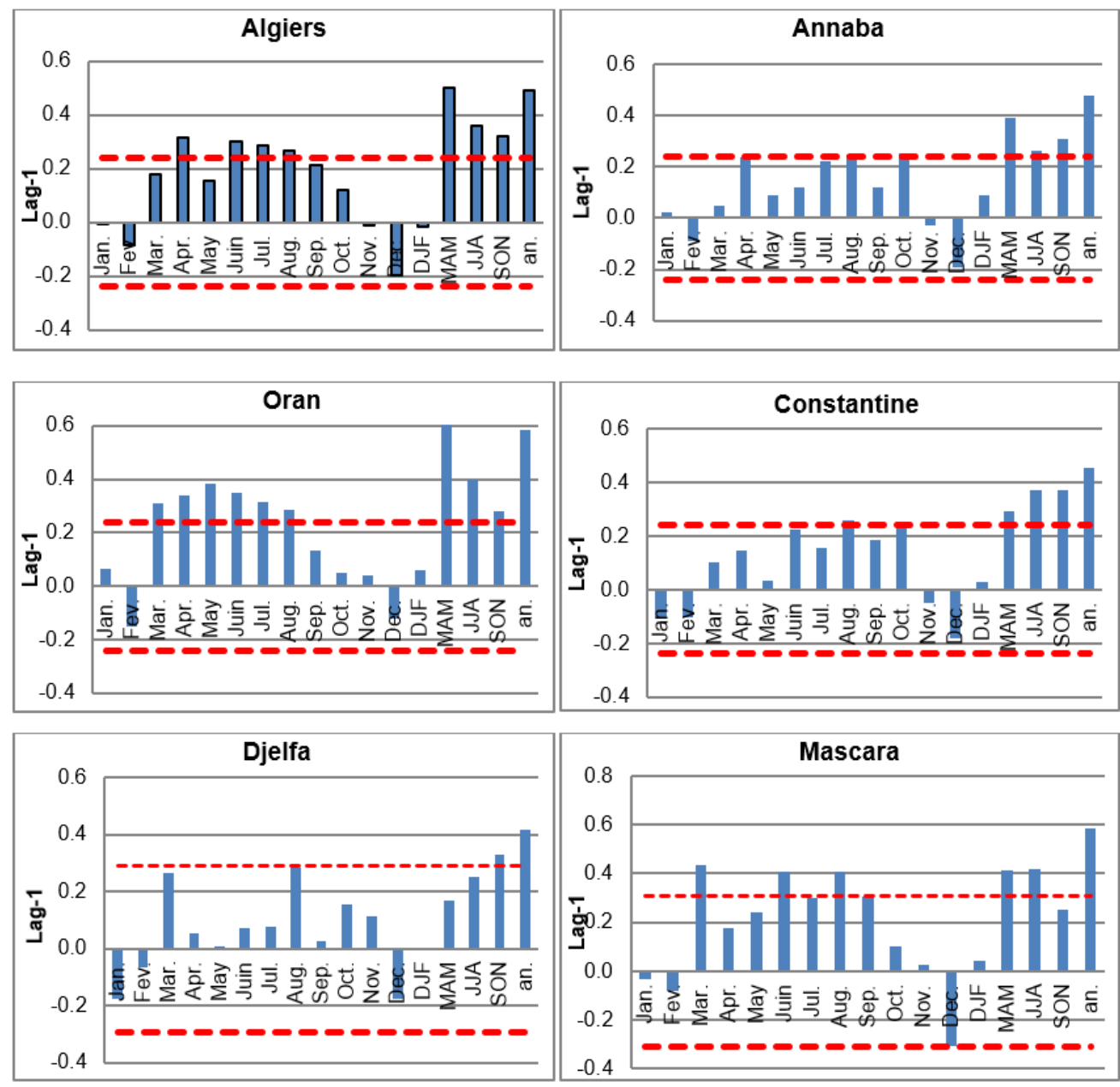

Figure 2 
Lag-1 auto-correlation for all time scales for each station

Page 24/24 